\title{
HIV treatment: mechanisms of neurotoxicity and implications for targeted therapy
}

REVIEW

This article was published in the following Dove Press journal:

Neurobehavioral HIV Medicine

3 September 2012

Number of times this article has been viewed

\author{
Chengxiang $\mathrm{Wu}^{1,2}$ \\ Yuanan Lu',2 \\ 'Department of Microbiology, \\ ${ }^{2}$ Department of Public Health \\ Sciences, University of Hawai'i, \\ Honolulu, HI, USA
}

Correspondence: Chengxiang Wu Departments of Microbiology and Public Health Sciences, University of Hawai'i at Manoa, 1960 East-West Road, Biomed Bldg, D I05, Honolulu, HI 96822, USA $\mathrm{Tel}+$ I 8089562684

Fax + I 8089565818

Email chengxia@hawaii.edu

\begin{abstract}
The central nervous system is known to act as a unique compartment where the human immunodeficiency virus (HIV) can replicate independently from the plasma and as a sanctuary in which the virus is largely protected from the host immune system and combination antiretroviral therapy. Although combination antiretroviral therapy has dramatically decreased the rate of HIV-caused mortality and associated diseases, neurological complications are increasingly common. However, our knowledge of the complicated pathogenesis and clinical symptoms of HIV-associated neurocognitive dysfunction is limited by a lack of complete understanding of the biology of HIV and its interaction with host cells in the central nervous system. This review focuses on the mechanisms of HIV entry and replication in the central nervous system neurotoxicity caused by viral proteins and cytokine/chemokines derived from affected host cells, their implications for targeted therapy, and advances in the development of animal models for novel therapeutics in the context of combination antiretroviral therapy regimens.
\end{abstract}

Keywords: HIV, HIV-associated neurocognitive dysfunction, neurotoxin, cytokines, chemokines, animal model

\section{Introduction}

Lentiviruses of human immunodeficiency virus type-1 (HIV-1) and HIV-2 are etiologic agents of the acquired immunodeficiency syndrome (AIDS). ${ }^{1} \mathrm{HIV}$ infection has become pandemic and the World Health Organization reported that approximately $0.6 \%$ of the world's population was affected by this virus in $2006 .^{2}$ AIDS caused over 1.8 million human deaths in 2009 including 260,000 children, which dropped from a global peak of 2.1 million in $2004 .{ }^{3}$ Since its discovery in 2006, AIDS caused the loss of 25 million human lives. ${ }^{2}$ Although treatment with combination antiretroviral therapy (cART) has reduced the mortality and morbidity of HIV infection and public awareness and preventive measures has been significantly intensified, and despite the effects of the natural course of the epidemic, an estimated 2.6 million people were newly infected in 2009. ${ }^{3}$ HIV infects cells in the immune system such as T-helper cells, macrophages, and dendritic cells, ${ }^{4}$ and leads to low levels of cluster of differentiation-4+ (CD4+) T-cells. When the CD4+ T-cell numbers decline below a critical level of 200 cells/ $\mu \mathrm{L}$, cell-mediated immunity becomes lost, secondary infections with a variety of opportunistic microbes appear, and most untreated HIV-infected people eventually develop AIDS. ${ }^{5}$

HIV infection not only destroys cells in the immune system, chronic viral infection also leads to the development of a variety of neurological syndromes. ${ }^{6} \mathrm{HIV}$ invades the central nervous system (CNS) shortly following primary infection, most likely soon 
after seroconversion, ${ }^{7,8}$ and subsequently induces progressive multiple systems of motor and cognitive dysfunction, psychiatric disturbances, and behavioral changes. ${ }^{9}$ Although the discovery of the neural expression of chemokine receptors as potential cellular binding sites for the virus and viral proteins - as well as progresses in neuroinflammation and neural stem cell biology - provides massive insights, ${ }^{10-16}$ mechanisms contributing to HIV-associated neuropathogenesis remain to be completely elucidated.

\section{HIV-associated neurocognitive dysfunction (HAND) associated with HIV infection}

HIV-positive patients develop HAND in the late phase of their infection. Pathological features such as neuronal loss, as well as cortical and subcortical atrophy, are revealed through examination of autopsied brains of HIV-positive individuals. ${ }^{17}$ Moreover, neurons in HIV-infected brains show dendritic and synaptic damage, and activation of apoptotic pathways ultimately leads to cell death. ${ }^{6,18,19}$ HAND includes asymptomatic neurocognitive impairment, minor neurocognitive impairment, and HIV-associated dementia, and remains among the most frequently occurring disorders in HIV-infected people, even in an era that cART is widely deployed. ${ }^{20-22} \mathrm{~A}$ related study published in 2010 by the CHARTER (CNS HIV Antiretroviral Therapy Effects Research) group showed that 52\% of HIV-infected adults exhibited signs of neuropsychological impairment. ${ }^{23}$ On the other hand, although cART has not dramatically changed the overall rate of this disease, it may alter presentation/severity of HAND from the fact that the asymptomatic neurocognitive impairment becomes the most common subdiagnosis in persons with HAND. ${ }^{24,25}$ Before the introduction of cART, the majority of severe neurological symptoms took place in the late stage of HIV infection, with an estimation of the prevalence of HIV-associated dementia to be as high as $20 \%-30 \%$ in patients with low CD4+ T-cell counts. ${ }^{26}$ Following the era of cART, the life expectancy of HIV-infected people has been extended and the incidence of HIV-associated dementia has decreased. ${ }^{23}$ This is consistent with reports of more pronounced impairment of executive function and memory/learning in the cART era, compared to the pre-cART period. ${ }^{22}$ For instance, new cases of moderate or severe dementia fell from approximately $70 \%$ in 1989 to only $1 \%$ in $2000 .{ }^{23}$ This leads to the point that the effects on the brain caused by HIV infection should be considered along with systemic conditions, and that peripheral infection, induced immune response, and inflammation processes can affect all cell types in the CNS. ${ }^{27,28}$ However, due to the poor efficiency of drug penetration into the CNS, as well as other as yet unclear mechanisms, cART fails to provide protection to HIV-1-infected patients from the development of HAND, or to reverse the disease. ${ }^{12,13,29}$ To develop effective therapeutics, a better clarification and understanding of the pathogenic mechanisms of HIV-associated neurotoxicity is important. For instance, chemokine receptors that mediate the HIV infection, such as C-X-C chemokine receptor type-4 (CXCR4) and C-C chemokine receptor type-5 (CCR5), play particularly important roles in neurotoxicity. ${ }^{30,31}$ CXCR4 and CCR5 mediate the infection of immunocompetent cells through the viral envelope glycoprotein-120 (gp120). ${ }^{32}$ Even though neurons are not infected by the virus, due to the fact that they express high levels of chemokine receptors, ${ }^{33,34}$ they are subjected to massive apoptotic cell death in the presence of HIV proteins. ${ }^{35-37}$ This has led to a hypothesis that the chemokine receptor signaling itself is responsible for the neuronal apoptosis and atrophy observed in individuals with HAND. ${ }^{6,18,19,38,39}$

\section{Other HIV-associated neurological diseases}

In addition to HAND, numerous neurological syndromes occur throughout the course of HIV infection that affects the CNS and peripheral nervous system. These HIV-associated neurological diseases either occur with opportunistic infections of the nervous system or are caused directly or indirectly by the virus itself. ${ }^{40}$ Some of these disorders are manifested early and some occur during the late stage of the infection, and the neuropathology includes inflammatory, demyelinating, and degenerative changes.

Early manifestations of these neurological diseases are relatively rare, and may occur following the initial infection, even before seroconversion. These early manifestations include aseptic meningitis or encephalitis, acute and chronic inflammatory demyelinating polyneuropathies, mononeuritis multiplex associated with peripheral nerve vasculitis, and HIV-associated polymyositis. ${ }^{41}$ Autoimmune pathogenesis is believed to be involved in these diseases, and patients with these diseases are typically responsive to immunosuppressive or immunomodulatory therapies in a similar manner to HIV-negative patients with the same diseases. ${ }^{42}$

Besides the early manifestations, neurological morbidity and mortality mainly occur following the onset of immunodeficiency with significantly lowered CD4+ T-cell count. Demyelinating leukoencephalopathy, which occurs in AIDS patients failing cART, is caused by massive infiltration of HIV-infected monocytes/macrophages into the brain with 
extensive white matter destruction. This may be attributable to the interaction of antiretrovirals with cerebrovascular endothelium, astroglial cells, and white matter, leading to cerebral ischemia, increased blood-brain barrier (BBB) permeability, and demyelination. ${ }^{43,44}$ Acute encephalopathy associated with the immune reconstitution inflammatory syndrome occurs in patients with advanced HIV disease with low CD4+ T-cell counts and high viral loads, caused by an acute infiltration of CD8+ T-cells into the CNS when treated with cART. It is suggested that the rapid immune reconstitution induced by cART leads to a redistribution of lymphocytes into the peripheral blood, followed by the recruitment of $\mathrm{CD} 8+$ lymphocytes into the brain, which results in diffuse infiltration. ${ }^{45-47}$ Vacuolar myelopathy is the most common chronic myelopathy associated with HIV infection, and often occurs in conjunction with AIDS dementia complex, peripheral neuropathies, and opportunistic infections or malignancies of the CNS or peripheral nervous system, eg, cytomegalovirus, progressive multifocal leukoencephalopathy, and lymphoma. ${ }^{4-50}$ Vacuolar leukoencephalopathy occurs during immune recovery following cART treatment, ${ }^{51}$ and the histopathology is similar to that of vacuolar myelopathy. ${ }^{52}$ In fulminant HIV dementia, symptoms progress over days and result in death within 2 months from the onset of neurological sysmptoms. ${ }^{53}$ In this disease, the basal ganglia is a common site of involvement for unclear reasons, ${ }^{54}$ and functional imaging and pathologic studies demonstrate the presence of basal ganglia abnormalities in HIV-infected individuals. ${ }^{55,56}$

Involvement of the peripheral nervous system is also part of AIDS. Like the CNS, the peripheral nervous system is a target of both the virus and other infectious agents. Although the development of neuropathic symptoms does not occur until the patient starts to show symptoms of early AIDS, electrophysiological evidence of peripheral nerve involvement is found in many patients with normal or near-normal CD4+ T-cell counts. Although pathological involvement of peripheral nerves is present virtually in all patients dying of AIDS, not all patients with HIV-1 infection develop clinical neuropathy, and the peripheral neuropathic symptoms may remain unrecognized or unappreciated in the presence of additional lesions in the spinal cord or brain in end-stage AIDS. ${ }^{57}$ However, HIV-associated sensory neuropathy (HIV-SN) represents major neurological disorder in persons with HIV/AIDS, affecting more than $30 \%$ of HIV-infected individuals globally. ${ }^{9}$ Painful peripheral neuropathy may actually be the most common and main neurological complication, and is also the most frequent neurological complaint observed among HIV-infected individuals in the industrialized world. ${ }^{57,58}$ Significant pain from HIV-SN affects up to $40 \%$ of HIV-infected individuals treated with cART. Prevalence of HIV-SN has increased despite increased access to and more widespread use of cART by infected individuals, and painful HIV-SN remains a major and expanding health problem worldwide. ${ }^{59} \mathrm{HIV}-\mathrm{SN}$ includes neuropathy directly related to HIV infection, eg, distal symmetrical polyneuropathy, and neuropathy associated with use of nucleoside analogs. Neuropathy associated with HIV infection alone should be distinguished from cART-induced toxic neuropathy, in that the latter is likely due to interferences with DNA integrity and mitochondrial dysfunction introduced by cART. ${ }^{60,61}$ However, cART-associated neuropathy may be caused by the synergism between the neurotoxicity of HIV infection and the neuropathy associated with cART. Furthermore, in all HIV-infected individuals, risk of infections, both opportunistic and nonopportunistic, increases as absolute CD4+ T-cell count falls, especially when fewer than 200 cells $/ \mu \mathrm{L}$, and nonopportunistic infections tend to be more common and more severe among HIV-infected individuals. HIV proteins may interact with the proteins introduced by these infections, particularly viral infections, and induce synergistic deleterious effects, which may play critical roles in the pathology of diseases, eg, cryptosporidiosis, microsporidiosis, and progressive multifocal leukoencephalopathy. ${ }^{62}$ For example, HIV transactivator of transcription (Tat) protein can transactivate the John Cunningham virus promoter in John Cunningham virus-infected oligodendrocytes, and may contribute to the neuropathogenesis of progressive multifocal leukoencephalopathy in patients with AIDS. ${ }^{63-67}$

Another burgeoning field that has attracted increasing interest is the interaction between intravenous drug abuse, HIV-1 infection, and neurological impairment. Abuse of intravenous drugs contributes substantially to the global HIV-1 epidemic, with $20 \%$ of intravenous drug users estimated to be infected with HIV-1. It causes about $30 \%$ of HIV-1 infections worldwide, except for sub-Saharan Africa, and is the third most frequently reported risk factor for HIV-1 infection in the United States. ${ }^{68,69}$ Risk behaviors associated with intravenous drug abuse is primarily the sharing of syringes. However, aside from providing a route of viral transmission, drug abuse also intrinsically affects HIV-1 pathogenesis, particularly in the CNS. Abuse of opiate drugs, such as heroin and morphine, promotes HIV-1 infection and the progression to AIDS through the suppression of cell-mediated immunity of the host, thus contributing to increased susceptibility to HIV infection and the eventual 
development of AIDS. ${ }^{70,71}$ In addition, opiate abuse appears to increase the frequency and severity of HAND through the activation of microglia, breakdown of the BBB, and direct neurotoxicity. ${ }^{72-74}$ Furthermore, recent studies have indicated that opiates can exacerbate the neurodegenerative effect of HIV-1 Tat protein and hasten the progression of HIV-associated dementia, ${ }^{75-78}$ possibly through eliciting high levels of nicotinamide adenine dinucleotide phosphatedependent reactive oxygen species and significant alterations in mitochondrial membrane homeostasis in neurons. ${ }^{79}$ Opiates can enhance the vulnerability of macroglia and macroglial precursors to the HIV-1 Tat protein through direct actions on glial precursors and/or astroglia. With sustained exposure to morphine, HIV-1 Tat protein induces preferential death of glial precursors and some astrocytes through processes that are mediated by $\mu$-opioid receptors and accompanied by the activation of caspase- $3 .^{80-82}$ In addition, opiates enhance HIV-1 Tat protein-induced inflammatory effectors that are released by glia, and consequently elevate reactive oxygen species, increase 3-nitrotyrosine production by microglia, and reduce the ability of glia to buffer glutamate. ${ }^{77}$ In addition to opiates, another common drug of abuse in HIV-1-infected individuals is methamphetamine, an extremely addictive sympathomimetic stimulant that is chemically similar to the CNS stimulant amphetamine, and abuse of either drug facilitates HIV transmission, promotes HIV infection of target cells, and causes more serious neurological impairment. ${ }^{83-86}$ Furthermore, although both HIV infection and methamphetamine abuse are known to be associated with neurological dysfunction in an independent manner, the combined effects of HIV infection and chronic methamphetamine use are consistent with a synergistic model and can lead to additional neuronal injury and glial activation due to the comorbid conditions. ${ }^{56,87-90}$

Although neurological complications of HIV infection are numerous, most current studies have been directed to understanding HAND, which is the main focus of this review, including HIV invasion and replication in the CNS, mechanisms of neurotoxicity, their implications for targeted therapy, and advances in development of animal models.

\section{HIV entry into the CNS}

Probably due to its immunological sequestration, CNS is believed to remain a viral reservoir throughout the course of viral infection..$^{91,92}$ Due to a significant difference in nucleotide sequences and biological properties that are observed on HIV-1 isolates from the brain and peripheral blood of the same patients, it is suggested that the brain may harbor the virus for many years. ${ }^{93} \mathrm{HIV}-1$ invades lymphoid and nervous systems through infecting target cells that contain major receptors, either CD4 or CD8, as well as various chemokine receptors as coreceptors that are typically found on T-cells, blood monocytes, and some dendritic cells. These receptors facilitate viral entry into host cells, ${ }^{94}$ and infected CD4+ T-cells and monocytes that circulate in the blood are a potential source of CNS infection. ${ }^{95}$

Of the chemokine receptors that are utilized by HIV-1, CXCR4 is found on lymphocytes, and CCR5 is found on monocytes, macrophages, and microglia. ${ }^{96}$ According to their use of coreceptors, HIV-1 is designated as R5 or X4 tropic, respectively, with some strains being dual tropic due to their use of both receptors. Within the CNS, HIV-1 infects mainly microglia and monocyte-derived macrophages. ${ }^{97}$ These cell types are the only cells that express both CD4 and CCR5 and they are the only cells that allow productive HIV-1 infection within the brain..$^{97,98}$ In addition to viral receptors, the intracellular environment plays an important role in HIV-1 replication. ${ }^{99}$ HIV-1-infected cells can be either highly active producers of progeny viruses or low/nonproducers, defined as "productive" or "restricted" infection. Productively infected cells support production of progeny virus, are engaged in transmission of infection as well as in the evolution of the viral genome, and die ultimately due to expression of toxic viral proteins. On the other hand, restrictedly infected cells are permissive to HIV-1 infection but are refractory to efficient viral gene expression, and thus do not support virus replication but serve as a virus reservoir with replication-competent viral genome. Although these cells do not produce viral structural proteins, they can express accessory proteins such as regulator of virion expression and negative regulatory factor. ${ }^{100,101}$ The restricted infection can be caused by blockage at various stages of the HIV-1 life cycle such as nucleocytoplasmic transportation, translation of viral ribonucleic acids (RNAs), assembly, or maturation of progeny virion. ${ }^{102}$ Restricted infection, however, can be reactivated by changes in the intracellular environment, such as increased expression of cytokines like tumor necrosis factor- $\alpha$ (TNF- $\alpha$ ), interleukin-6 (IL-6), and IL-1 $\beta .{ }^{13,103-106}$

The $\mathrm{BBB}$, or cerebrospinal fluid (CSF)-brain barrier, also plays a crucial interactive role during HIV-1 infection of the CNS. ${ }^{107}$ The BBB is selectively permeable and constitutes a barrier for the exchange of cells and substances between the brain parenchyma and the bloodstream. ${ }^{95}$ In order to get entry into the brain, HIV has to cross the BBB through a mechanism (or mechanisms) that is not yet completely understood. Current studies support the entry of HIV-1 into the CNS either as a free virus, via release 
of the virus into the brain by infected brain microvascular endothelial cells (BMVECs), or via infected immune cells. ${ }^{108}$ Although several studies identified HIV-1 structural proteins in BMVECs by immunohistochemistry, ${ }^{109-111}$ the study by Bagasra et al primarily identifies HIV-1 DNA and messenger RNAs for regulatory factors, but not for structural proteins, ${ }^{98}$ leading to the postulation that BMVECs are restrictedly infected. On the other hand, although it is possible that cell free viruses are able to cross the BBB, infected CD4+ T-cells and macrophages are more likely sources of initial neuroinvasion, ${ }^{112,113}$ which is verified by histological studies from simian immunodeficiency virus (SIV)-infected rhesus macaques and HIV-1-infected humans demonstrating that lymphocytes and monocytes are capable of infiltrating into the brain. ${ }^{114,115}$ Whilst pathophysiological significance of the CNS-infiltrating lymphocytes in HAND is subject to further delineation, ${ }^{115,116}$ current evidence suggests that cell-free HIV-1 particles may penetrate BMVECs through a mitogen-activated protein kinase-dependent macropinocytosis, ${ }^{112,117}$ and this process can be enhanced by lipopolysaccharide treatment. ${ }^{118}$ BMVECs exposed to HIV-1 express an elevated amount of intercellular adhesive molecules such as intercellular adhesion molecule-1, which in turn may facilitate leukocyte migration across the BBB and offer access for both cell-free viral particles and infected monocytes/macrophages into the CNS. ${ }^{113,119-122}$ Furthermore, proinflammatory cytokines, eg, TNF- $\alpha$, and oxidative stress can increase BBB permeability by activation of guanylate cyclase and tyrosine kinase. ${ }^{123,124}$

Regardless of the potential roles of infected lymphocytes, cell-free viruses, and BMVECs, the generally accepted model of HIV entry into the CNS, with the most compelling evidence, is that HIV enters the brain through infiltration of infected T-cells and monocytes, with the latter later differentiating into macrophages. This mechanism is known as the "Trojan horse" hypothesis. ${ }^{125,126}$ According to this hypothesis, $\mathrm{HIV}$ and other lentiviruses cross the $\mathrm{BBB}$ and migrate into the CNS by hiding in infected cells trafficking to the brain. Besides HIV, other viruses, eg, visna virus, feline immunodeficiency viruses (FIV), SIV, and human T-cell leukemia virus type-1, have also been reported for being transported into the brain by infected monocytes and macrophages. ${ }^{127-129}$ Therefore, Trojan horse might represent a common route for retroviral and lentiviral penetration into the brain.

\section{HIV-associated neurotoxins}

Pathogenic mechanisms behind HIV infection-associated CNS dysfunction have not reached a common agreement.
Whilst it is generally accepted that neurons are not infected by HIV, the primary cause/mechanism of neuronal damage remains unclear. There are discrepancies between distribution and number of HIV-infected cells, severity of the clinical course, and brain tissue pathology. This may suggest other mechanisms than direct viral cytotoxicity as causes of CNS damage. ${ }^{130}$ However, current evidence supports that neuronal damage can be caused by various HIV proteins, such as Tat, $\mathrm{R}$ protein (Vpr), negative regulatory factor, gp120, and gp41. ${ }^{11,12}$ This has led to two different theories on how dysfunction in the CNS is caused, both centering on the productive infection of brain macrophages/macroglia. These theories are named "direct injury" and "indirect injury," with the latter also called "bystander effect,"12 and they are not mutually exclusive. Although the indirect form of neurotoxicity seems to predominate, ${ }^{11,131,132}$ current evidence supports a role for both. The direct injury hypothesis suggests that HIV proteins can directly cause neuronal injury without effects from intermediary functions of nonneuronal cells such as microglia and/or astrocytes, and the indirect hypothesis suggests neuronal dysfunction caused through immunoactivation of nonneuronal cells by HIV infection or shed viral proteins.

\section{Virotoxins from HIV}

HIV viral proteins are potentially neurotoxic through either direct or indirect mechanisms, or both ${ }^{36,133-136}$ with more information summarized in Table 1. Neurotoxicity caused directly by viral proteins is supported by evidence that gp120, which is soluble and can be shed from HIV-infected cells, has been demonstrated to be toxic to cultured neurons at low concentrations, ${ }^{36,137}$ and can directly injure neurons in serum-free primary neuronal cultures and in neuroblastoma cell lines. ${ }^{35,138,139}$ Evidence that blocking chemokine receptor signaling can prevent gp120-induced neuronal apoptosis suggests that gp120 is capable of interacting with several chemokine receptors in the absence of CD4, and HIV-induced neuronal injury may be directly mediated by distinct chemokine receptor signaling pathways. ${ }^{39,140-142}$ Other evidence that gp120 interacts with the N-methyl-D-aspartate-type glutamate receptor (NMDAR) suggests another mechanism by which gp120 may directly cause neuron injury. ${ }^{143,144}$ The other cleavage product of gp 160 , gp41, is neurotoxic through induction of nitric oxide. ${ }^{133,145}$ Besides the envelope proteins, Tat is secreted by infected cells and may also directly induce neuronal apoptosis via a pathway involving disruption of the metabolic balance of lipoprotein receptor-related protein ligands and direct activation of neuronal genes, ${ }^{146}$ or via an increase in intracellular calcium, 
Table I Virotoxins from HIV proteins

\begin{tabular}{|c|c|c|c|}
\hline $\begin{array}{l}\text { HIV } \\
\text { proteins }\end{array}$ & Localization & $\begin{array}{l}\text { Mode of } \\
\text { action }\end{array}$ & Mechanism \\
\hline gp 120 & $\begin{array}{l}\text { Membrane of infected cell; secreted } \\
\text { into extracellular milieu }\end{array}$ & $\begin{array}{l}\text { Direct and } \\
\text { indirect injury }\end{array}$ & $\begin{array}{l}\text { Interfere with N-methyl-D-aspartate receptor; create oxidative } \\
\text { stress; immunoactivation of monocyte/macrophage, microglia, } \\
\text { and astrocytes; stimulate release of cytokines }\end{array}$ \\
\hline gP4I & $\begin{array}{l}\text { Membrane of infected cell; } \\
\text { ectodomain aggregates in the brain }\end{array}$ & $\begin{array}{l}\text { Direct and } \\
\text { indirect injury }\end{array}$ & $\begin{array}{l}\text { Induction of neurocytokines; production of nitric oxide through } \\
\text { an inducible nitric oxide synthase }\end{array}$ \\
\hline Tat & Secreted into extracellular milieu & $\begin{array}{l}\text { Direct and } \\
\text { indirect injury }\end{array}$ & $\begin{array}{l}\text { Apoptosis via disruption of the balance of LRP ligands and } \\
\text { activation of host genes; increases intracellular calcium; production } \\
\text { of reactive oxygen intermediates; activation of caspase; activation } \\
\text { of cells of immune system; stimulate release of cytokines }\end{array}$ \\
\hline Rev & Unknown & Direct injury & $\begin{array}{l}\text { Cause nucleolar ballooning and deformity with aberrant } \\
\text { accumulation of ribosomal ribonucleic acids }\end{array}$ \\
\hline Vpr & $\begin{array}{l}\text { Detected in CSF of people } \\
\text { with HAND }\end{array}$ & Direct injury & $\begin{array}{l}\text { Form cation-selective ion channels across cell membrane, causing a } \\
\text { large inward cation current and depolarization of the plasmalemma }\end{array}$ \\
\hline Nef & $\begin{array}{l}\text { Detected on the surface of infected } \\
\text { cells; secreted into extracellular milieu }\end{array}$ & Direct injury & $\begin{array}{l}\text { Share sequence and structural features with scorpion peptides; } \\
\text { reversibly increase the total potassium current }\end{array}$ \\
\hline Vpu & Unknown & Direct injury & Increase ion channel activity; interact with Fas \\
\hline Vif & Unknown & Unknown & Unknown \\
\hline Gag & $\begin{array}{l}\text { Intracellular expression; assembly } \\
\text { into virion-like particles }\end{array}$ & Unknown & Unknown \\
\hline
\end{tabular}

Abbreviations: CSF, cerebral spinal fluid; Fas, tumor necrosis factor receptor superfamily, member 6; Gag, group-specific antigen; gp, glycoprotein; HAND, human immunodeficiency virus-associated neurocognitive dysfunction; HIV, human immunodeficiency virus; LRP, lipoprotein receptor-related protein; Nef, negative regulatory factor; Rev, regulator of virion expression; Tat, transactivator of transcription; Vif, viral infectivity factor; $V_{p r}$, viral protein R; $V_{p u}$, viral protein $U$.

thereby stimulating production of reactive oxygen intermediates and caspase activation. ${ }^{147}$ More recent evidence suggests that Tat toxicity is dependent upon a polyamine-sensitive site on NMDAR. ${ }^{148}$ In addition, Tat and negative regulatory factor have been reported to increase production of neurotoxic quinolinic acid, a glutamate receptor agonist. ${ }^{149} \mathrm{Vpr}$ is capable of causing apoptosis in human neurons (via cytochrome c extravasation), protein 53 induction, activation of caspase-9, and exerting a depressive effect on whole-cell currents in neurons. ${ }^{150}$ Another study using cultured hippocampal neurons revealed that $\mathrm{Vpr}$ causes a large inward cation current and depolarization of the plasmalemma, eventually resulting in cell death. ${ }^{151}$

Although several HIV proteins have been reported to cause neurotoxicity, further studies are necessary to determine whether or not the concentrations of these proteins required for neurotoxicity in vitro are within the range that is present in vivo in an infected brain, ${ }^{108}$ and findings from these in vitro experiments should be interpreted under context of the specific conditions of the experimental paradigm, ${ }^{152}$ in that most of the results are obtained in the absence of nonneuronal cells and therefore predominantly the indirect effect is not involved. Moreover, concentrations of the HIV proteins employed in these studies are frequently significantly higher than the picomolar or lower range that is thought to be present in the brain or CSF of patients with HIV-associated dementia. ${ }^{152}$
Besides neuronal injury caused directly by HIV proteins, other in vitro evidence suggests that gp 120 neurotoxicity may occur indirectly and rely on the presence of toxic intermediates and activated chemokine receptors on macrophages/ microglia. ${ }^{108}$ These toxic intermediates include proinflammatory cytokines and arachidonic acid metabolites that are produced when macrophages/microglia cells are exposed to gp $120 .^{36,153}$ Tat is also capable of causing neurotoxicity indirectly via stimulation of macrophages to produce matrix metalloproteinases that are capable of inducing neuronal apoptosis. ${ }^{134,154}$ Another model proposes that astrocytes may be involved in mediating such toxicity, ${ }^{155,156}$ supported by experimental findings that nitric oxide synthase is induced in astrocytes exposed to gp120, ${ }^{157,158}$ and the nitric oxide production may impair the ability of astrocytes to protect neurons from damage. In vitro, neuronal toxicity and apoptosis has been demonstrated through the use of X4 and R5 dual tropic envelopes, which is consistent with the finding that CXCR4 is present in a number of neural cell types. ${ }^{159,160}$

\section{Toxins from host cells affected by HIV}

Various cell types in the brain can be infected by HIV and/ or dysregulated by HIV proteins as summarized in Table 2. Severity of HIV encephalitis, a pathological correlate of the most severe form of HAND, correlates better with glial activation rather than viral load. It is often characterized by multinu- 
Table 2 Influence on host cells by virotoxins

\begin{tabular}{|c|c|c|c|}
\hline Cells of origin & Source of influence & Upregulation & Downregulation \\
\hline $\begin{array}{l}\text { Monocytes/macrophages, } \\
\text { microglia }\end{array}$ & $\begin{array}{l}\text { gp I20, gp4l, } \\
\text { Tat, Nef, Vpu }\end{array}$ & $\begin{array}{l}\text { TNF- } \alpha \text {, IL-I } \beta \text {, IL-6, PGE2, protein } 53 \text {, NTox, TGF } \beta \text { I, } \\
\text { endothelin-I, CCR5, platelet activating factor, MMP-9 }\end{array}$ & cAMP by Tat \\
\hline Astrocytes & $\begin{array}{l}\text { gp I20, gp4l, } \\
\text { Tat, Nef, Vpr }\end{array}$ & $\begin{array}{l}\text { iNOS, tyrosine kinase, ICAM-I, CXCLI0, endothelin-I, CD23, } \\
\text { complement factor-3, IL-6, IL-8, IL-I0, MMP-I, MMP-2, MCP-I, } \\
\text { Id-I, GFAP, VCAM-I, PKC, NF-KB, MAPK, JNK }\end{array}$ & $\begin{array}{l}\beta \text {-adrenergic function, } \\
\text { glutamate influx, GFAP, } \\
\text { glutamate transporter EAAT2 }\end{array}$ \\
\hline BMVECs & $\begin{array}{l}\text { gp I20, gp4I, } \\
\text { Tat, Nef, Vpu }\end{array}$ & $\begin{array}{l}\text { ICAM-I, } \mu \text {-opioid receptor, PKC, MCP-I, IL-6, IL-8, } \\
\text { E-selectin, NF-אB, AP-I, FAK, iNOS }\end{array}$ & Claudin-I, claudin-5, ZO-2 \\
\hline Neurons & $\begin{array}{l}\text { gp I20, gp4I, } \\
\text { Tat, Nef, Vpr }\end{array}$ & $\begin{array}{l}\text { Calcium uptake, CXCR4, oxidative stress, sphingomyelinase, } \\
\text { protein 53, PKC, NMDAR, JNK, ERK, CXCLI0, calcium } \\
\text { release from IP-3 pool, GSK-3 } 3, \text { MAPK, quinolinic acid }\end{array}$ & $\begin{array}{l}\text { BDNF, neuron specific } \\
\text { enolase, glutathione, } \\
\text { neprilysin, LRP ligands }\end{array}$ \\
\hline
\end{tabular}

Abbreviations: AP-I, activator protein-I; BDNF, brain-derived neurotrophic factor; BMVECs, brain microvascular endothelial cells; cAMP, cyclic adenosine monophosphate; CCR5, C-C chemokine receptor type-5; CD23, cluster of differentiation-23; CXCLI0, C-X-C chemokine ligand-I0; CXCR4, C-X-C chemokine receptor type-4; EAAT2, excitatory amino acid transporter-2; ERK, extracellular signal-regulated kinase; FAK, focal adhesion kinase; GFAP, glial fibrillary acidic protein; gP, glycoprotein; GSK-3ß, glycogen synthase kinase-3 $\beta$; ICAM-I, intercellular adhesion molecule-I; Id-I, inhibitor of DNA binding-I; IL, interleukin; iNOS, inducible nitric oxide synthase; IP-3, inositol triphosphate; JNK, c-Jun N-terminal kinase; LRP, lipoprotein receptor-related protein; MAPK, mitogen-activated protein kinase; MCP-I, monocyte chemotactic protein-I; MMP, matrix metalloproteinase; Nef, negative regulatory factor; NF- $\kappa B$, nuclear factor- $\kappa B$; NMDAR, N-methyl-D-aspartate-type glutamate receptor; PGE2, prostaglandin E2; PKC, protein kinase C; Tat, transactivator of transcription; TGF $\beta$ I, transforming growth factor- $\beta$ I; TNF- $\alpha$, tumor necrosis factor- $\alpha$; VCAM-I, vascular cell adhesion molecule-I; $V_{p r}$, viral protein $\mathrm{R}, \mathrm{V}_{\mathrm{pu}}$, viral protein $\mathrm{U}$; ZO-2, zona occludins-2.

cleated giant cells, widespread reactive astrocytosis, activated resident microglia, microglial nodules, cytokine/chemokine dysregulation, and infiltration by monocytoid cells including mainly blood-derived mono- and multinucleated macrophages, as well as neuronal loss. ${ }^{161}$ In addition, a variable degree of white matter and deep gray matter pathology with evidence of a broad range of myelin damage, and the presence of HIV-1 in the CSF, have been reported. ${ }^{162}$ Degree of neurocognitive impairment, however, does not correlate well with the presence and amount of HIV-infected cells in the brain, the presence of multinucleated giant cells and microglial nodules, nor the concentration of viral antigens in CNS tissue ${ }^{163,164}$ In contrast, pathologic features that are most firmly associated with the clinical signs of neurodegeneration include increased numbers of microglia, ${ }^{163,165}$ elevated TNF- $\alpha$ messenger RNA in microglia and astrocytes, ${ }^{166-169}$ evidence of excitotoxins, ${ }^{170,171}$ decreased synaptic and dendritic density, ${ }^{165,172,173}$ selective neuronal loss, ${ }^{174,175}$ and signs of neuronal apoptosis. ${ }^{176-178}$ Furthermore, severity of neuronal apoptosis is topographically correlated with structural atrophy, signs of microglial activation, and axonal damage, especially within the subcortical deep gray structures. ${ }^{179}$

The number of activated macrophages in the white matter correlates well with the pathology of HIV dementia. ${ }^{130,180}$ Multinucleated giant cells that are derived from HIV infection-induced fusion of macrophages, microglial nodules, and perivascular mononuclear inflammation are hallmarks of HIV dementia pathology. ${ }^{181-183}$ A clear association between the amount of circulating activated monocytes and the development of HIV dementia has been established, ${ }^{184,185}$ which is likely caused by increased inflammatory mediators from these monocytes and/or infected monocytes that are increasingly trafficking into the brain. ${ }^{186}$

Although brain macrophages and microglia from HIVinfected individuals may have neuroprotective properties, especially in the early phase of the infection, ${ }^{187,188}$ their predominant roles in the pathogenesis of HIV dementia are neuroinflammatory and neurotoxic - through the increased expression of cytokines such as TNF- $\alpha$, IL-1, interferon- $\alpha$, and inducible nitric oxide synthase. ${ }^{189-192}$ Furthermore, a number of neurotrophins are normally secreted by macrophages, ${ }^{193} \mathrm{eg}$, brain-derived neurotrophic factor, insulin-like growth factor, $\beta$-nerve growth factor, transforming growth factor- $\beta$, neurotrophin- 3 , neurotrophin- $4 / 5$, and glialderived neurotrophic factor. ${ }^{194-202}$ Expression of these neurotrophins is affected by cytokines and growth factors. ${ }^{203-205}$ For instance, acidic fibroblast growth factor induces higher IL-4, IL-10, and IL-13 levels, as well as expression of nerve growth factor and brain-derived neurotrophic factor in transected rat spinal cords. ${ }^{203}$ Cytokine mixtures derived from monocytes/macrophages induce a unique pattern of changes in genes for neurotrophins, growth and maturation factors, and related receptors through the downregulation of an alternatively spliced form of neurotrophin-3 growth factor receptor (trkC). ${ }^{204}$ Consequently, a dysregulation of macrophage-derived neurotrophic factors by viral infection or immunoactivation occurs during the course of HIV infection, which may elicit neuronal damage to considerable extent via the production of neurotoxins. ${ }^{186}$

Cytokines and chemokines, particularly those expressed by activated macrophages, appear to play a prominent role in the pathogenesis of HAND and other neurological com- 
plications of HIV. Although the relationship is not definitively demonstrated, current evidence shows that elevated levels of CSF and serum TNF- $\alpha$ correlate with presence of dementia. ${ }^{186}$ Although TNF- $\alpha$ may mediate neuroprotection under certain circumstances, ${ }^{206-209}$ it is neurotoxic through multiple regulatory roles, eg, promoting formation of reactive oxygen species, inhibiting glutamate uptake by glial cells, ${ }^{210,211}$ increasing the activation of NF- $\mathrm{kB},{ }^{212}$ expression of inducible nitric oxide synthase, ${ }^{212}$ inducing other chemokines and cytokines such as IL-6, IL-8, and CXCL10, ${ }^{213}$ upregulating expression of endothelial intercellular cell adhesion molecules, ${ }^{214,215}$ increasing the permeability of the BBB and subsequently facilitating HIV-infected monocytes entry into the brain, ${ }^{216}$ and promoting HIV replication. ${ }^{217,218}$

In addition to macrophages/microglia, reactive astrocytes are also commonly observed in the brains of HIV-infected individuals. ${ }^{219-221}$ Astrocytes do not possess $\mathrm{CD} 4$ receptor, but they express CXCR4 and possibly other coreceptors including CCR5 ${ }^{101,222,223}$ In the brain, whilst macrophages and microglia are productively infected, astrocytes are involved in restricted infection through a CD4-independent pathway and viral regulatory proteins are expressed. ${ }^{224,225}$ Since HIV invasion of the CNS occurs early following initial infection, substantial infection of astrocytes is therefore likely to take place before cART is initiated, and the infected astrocytes can thus serve as a significant source of viral proteins that are not affected by cART. These toxic viral proteins in turn are capable of stimulating the release of other neurotoxic substances from affected glial cells and macrophages, or otherwise altering glial cell function and leading to the loss of support for neurons. ${ }^{77,184,226-230}$ Furthermore, activated astrocytes themselves - induced by HIV Tat and gp120 - are also capable of secreting inflammatory mediators such as TNF- $\alpha .{ }^{231}$

Besides glia, macrophages, and astrocytes, BMVECs may play a role in the pathogenesis of HIV in the CNS. Although direct infection of endothelial cells with HIV remains uncertain, cells exposed to HIV or viral proteins may undergo apoptosis $^{232-237}$ or increase expression of adhesion molecules, ${ }^{238}$ consequently enhancing monocyte adhesion. ${ }^{239}$ The mechanisms implicated involve the activation of vascular endothelial growth factor receptor and phosphatidylinositol 3-kinase, ${ }^{232,235,237}$ as well as the induction of oxidative stress. ${ }^{236,240}$ Dysfunction of BMVECs may also play an important role in regulating the penetration of antiretroviral drugs across the BBB. ${ }^{240-243}$

\section{Implications for targeted therapy}

Although the introduction of cART has significantly reduced the morbidity and mortality rate of HIV infection, it cannot provide complete protection for HIV-infected individuals from HAND, largely due to inefficient drug delivery across the BBB. ${ }^{244-247}$ HAND, as well as sensory neuropathies, remain common in the cART era, with up to half of HIV-1 patients affected. ${ }^{22,248}$ Although cART regimens may be able to play more significant roles in the prevention/treatment of HAND with the development of improved delivery systems, the challenging complexity of the treatment of AIDS patients impedes previous approaches to coping with HAND. ${ }^{249,250}$ Approaches tested so far include various antiretroviral compounds, applied either alone or in combination, including abacavir, amprenavir, atazanavir, darunavir, didanosine, efavirenz, emtricitabine, enfuvirtide, etravirine, fosamprenavir, indinavir, lamivudine, lopinavir, maraviroc, nelfinavir, nevirapine, raltegravir, ritonavir, saquinavir, stavudine, tenofovir disoproxil, zalcitabine, and zidovudine. ${ }^{251-254}$ However, due to poor penetration across the BBB, effects of most of these drugs are limited. Drugs that belong to the nucleoside reverse transcriptase (RT) inhibitor group have the advantage of good penetration because of low molecular weight and the lowest rates of protein binding; among which, zidovudine has the best partition coefficient in the brain and cerebral tissue. However, it is not long lasting in spite of the beneficial effect it has on crossing the BBB..$^{254}$ In the current anti-HIV armamentarium, nevirapine, indinavir, lopinavir, amprenavir, abacavir, zidovudine, stavudine, emtricitabine, darunavir, and raltegravir are the only ones found to have CSF levels that are sufficient to inhibit HIV replication. ${ }^{255}$ This dilemma calls for further development of alternative strategies other than antiretroviral drugs for the treatment of HIV in the CNS. ${ }^{12}$ Among these, agents such as NMDAR antagonists, cytokines, chemokines, chemokine and cytokine receptor antagonists, protein 38 mitogen-activated protein kinase inhibitors, caspase inhibitors, and antioxidants can be considered. ${ }^{152}$

Studies have shown that neuronal damages caused either indirectly through HIV-infected macrophages or directly by the HIV proteins, both in vitro and in vivo, can be attenuated through NMDAR antagonists. ${ }^{256-258}$ One such agent, memantine - which inhibits excessive NMDAR activity while maintaining physiological function, is capable of blocking the neurotoxicity of HIV-1 gp120 and Tat in vitro, ${ }^{147,259,260}$ as well as improving synaptic transmission in hippocampal brain slices in a mouse model of HIV encephalitis and other studies. ${ }^{260-262}$ In addition, memantine has proven safe and effective in a number of clinical trials for amyotrophic lateral sclerosis, Alzheimer's disease, and vascular dementia. Furthermore, it provides clinical benefits in the functional abilities of patients with moderate to severe Alzheimer's disease. ${ }^{263-268}$ 
However, it does not induce significant improvement in the neuropsychological tests of patients with moderate-to-severe neurocognitive impairment during a 16-week treatment despite magnetic resonance spectroscopy demonstrating potential neuroprotective effects, as reflected by an improvement of the neuronal metabolism in the frontal white matter and parietal cortex of treated patients. ${ }^{262}$ In a subsequent open-label trial, long-term use of memantine for up to 60-weeks did not provide clear evidence of cognitive benefit. ${ }^{269}$ Besides NMDAR antagonists, calcium channel blockers, CCR5 antagonists, TNF antagonists, and platelet-activating factor antagonists used in small clinical trials suggest some therapeutic benefit but fail to show clear cognitive improvement. ${ }^{152,270-277}$

To combat the effects of excitotoxicity through minimizing the impact of free radicals, antioxidants are tried in an attempt to reduce oxidative stress-induced neuronal injury due to the toxic interactions between HIV-infected macrophages and neurons. One study utilizing OPC-14117, a lipophilic antioxidant, shows only a trend toward cognitive improvement. ${ }^{278}$ Two studies using selegiline and transdermal selegiline show significant efficacy on HAND, ${ }^{279,280}$ but in larger trials show neither cognitive benefit ${ }^{280,281}$ nor changes in brain metabolism. ${ }^{282}$ Studies using antiapoptotic drugs are also conducted to prevent or delay neural injury, with no clear benefit observed in neuropsychological measures. ${ }^{283,284}$ However, in one of these studies, neuroimaging reveals a decrease in the glutamate/glutamine ratio peak in the frontal grey matter, an increase in fractional anisotropy, a decrease in mean diffusivity in several brain areas, and changes in brain activation patterns, thus suggesting improvement of the HIV-associated CNS injury. ${ }^{284}$

Other chemicals, such as minocycline and valproic acid, have also been tested. ${ }^{285,286}$ Sodium valproate (VPA) functions as a mood stabilizer that moderates signal transduction. ${ }^{287}$ Because mood changes to the level of disorders are one of the problems associated with HIV-1 disease, VPA might be beneficial when incorporated into the therapeutic armamentarium for HAND. Studies have shown that VPA inhibits the apoptosis-inducing glycogen synthase kinase$3 \beta,{ }^{286,288}$ a multifaceted kinase involved in numerous cell processes and known to be present in platelets. ${ }^{289,290}$ Glycogen synthase kinase- $3 \beta$ is activated by the platelet-activating factor, ${ }^{291}$ an inflammatory instrument that is upregulated during HIV-1 infection, ${ }^{292}$ and is thought to play a role in cytoskeletal rearrangement and lamellipodia formation in some cell types. ${ }^{293,294}$ When used at the therapeutic concentration $(0.6 \mathrm{mM})$, VPA significantly increases $\beta$-catenin protein levels, decreases the level of protein $\alpha$-kinase $\mathrm{C}$ and epsilon isozymes, ${ }^{295}$ and downregulates the myristoylated alanine-rich $\mathrm{C}$-kinase substrate through inositol-independent mechanisms. ${ }^{287,296,297}$ However, it is suggested that further studies of VPA in advanced HIV infection should cautiously include high doses over prolonged periods of at least 18 months so that it can be more accurately determined whether the posited neuroprotective benefit of VPA still occurs or whether it is replaced by toxicity. ${ }^{298}$

Several lines of evidence have shown that some cytokines, eg, IL-4, IL-5, IL-6, IL-10, IL-11, and interferon- $\alpha$, may be capable of protecting neurons through antiinflammatory effects. ${ }^{299-303}$ These antiinflammatory cytokines may confer protection by antagonizing proinflammatory substances released from activated macrophages/microglia, or by inhibiting production of the inflammatory cytokines and activation of macrophages/microglia. ${ }^{287}$ In addition, erythropoietin, a cytokine that controls erythropoiesis, acts synergistically with another cytokine, insulin-like growth factor-1, as neuroprotectants by activating the phosphatidylinositol 3-kinase/ protein kinase B pathway. ${ }^{263,304,305}$ Besides the application of an antiinflammatory cytokine, chemokine/cytokine receptors may represent potential therapeutic targets against HAND or AIDS. For instance, antagonists of CXCR4 and CCR5 may be capable of inhibiting HIV entry into cells, ${ }^{12}$ and expression of a soluble TNF- $\alpha$ receptor-Fc fusion protein confers protection of neuron cells from TNF- $\alpha-$, HIV-1 Tat-, and gp120-mediated neurotoxicity. ${ }^{139}$ Furthermore, expression of these molecules in genetically modified cells, such as monocytes and macrophages that possess a natural capability of crossing the BBB, and use of the genetically modified cells as delivery vehicles into the CNS, may constitute a novel gene therapy strategy against the neurological complications of AIDS. ${ }^{306}$

Certain chemokines appear to be capable of protecting HIV-associated neurotoxicity, despite the fact that neurons are not infected by HIV. For example, fractalkine and $\beta$-chemokines are capable of preventing gp120induced neuronal apoptosis in vitro, ${ }^{35,36,76,307,308}$ and some $\beta$-chemokines can ameliorate NMDAR-mediated neurotoxicity similarly. ${ }^{307,309}$

Neurotrophic factors, eg, brain-derived neurotrophic factor, glial-derived neurotrophic factor, and neurotrophin-3, are constitutively expressed in the CNS. ${ }^{310-313}$ Dysregulation of neurotrophic factors are known to be associated with neurotoxicity and affect pathogenesis of HAND, ${ }^{314}$ with downregulation of neurotrophic factors contributing to neuronal injury and death. ${ }^{314-317}$ Through binding of their cognate receptors, neurotrophins act to limit neurotoxin- and 
lesion-induced neuropathologic damage and affect individual neuronal populations, dendritic length, spine density, synaptic transmission, antiapoptotic signaling, and signaling to limit oxidative stress. ${ }^{310,318-324}$ Moreover, neurotrophins confer neuronal protection by preventing apoptosis. ${ }^{325-328}$

Since caspases are essential in the regulation of the apoptotic program, their inhibitors may be capable of forestalling apoptosis and thwarting neuronal loss. ${ }^{329-331}$ Similarly, protein 38 mitogen-activated protein kinase inhibitors have been shown to protect neurons from apoptosis that is caused by excitotoxicity, HIV/gp120 exposure, or a chemokine (stromal cell-derived factor-1)-mediated toxicity. ${ }^{324,332-334}$

The future development of drugs for the treatment of HAND probably needs to focus on solving the challenges currently confronting the detection and treatment of HAND. First, the optimal cART regimen in terms of preventing and curing HAND, whether cART has neurotoxic effects, and the causative compounds if cART shows neurotoxicity need to be determined. Second, new therapies with minimal or no neuronal damage need to be developed. Given that the results of clinical trials so far with antiinflammatory and/or neuroprotective agents were largely disappointing, newer compounds, administered either alone or in combination, in large and long-term studies are necessary. Third, biomarkers to differentiate patients developing HAND and those developing other neurodegenerative diseases and to detect changes in clinical settings need to be identified. Overcoming these challenges would be of great significance for the development of new therapeutics against HAND.

\section{Application of animal models}

Finding an appropriate animal model for HIV has proven difficult. HIV naturally infects human beings and can only infect a small number of nonhuman primate species. ${ }^{335}$ This has severely limited the development of animal models for the study of HIV infection and HAND. An ideal animal model would be one that maintains the virological, immunological, and pathological aspects of human HIV infection and disease. However, such an animal model remains to be developed. It is important to acknowledge that each of the currently available animal models has its limitations. Accordingly, ongoing comparison of results obtained in animal models with those observed in human studies is necessary for the validation of the various models and for further improvement. ${ }^{336}$

Currently, although infection with several lentiviruses of certain farm animals results in slowly progressive degenerative diseases, these viruses infect only macrophages/ monocytes and not CD4+ T-helper cells. Consequently, they do not cause immunosuppression in the infected hosts, thus their relevance as a model for HIV immunopathogenesis is limited, ${ }^{337}$ and models that have been used for HIV study are mainly based on mouse/rats, felines, and nonhuman primates. Table 3 provides a summary of the advantages and disadvantages of the animal models used for HIV study.

\section{Mouse/rat models}

A mouse model is attractive for HIV-1 research because it can be maintained in inbred strains, can be easily genetically engineered, and their immune system is extensively

Table 3 Advantages and disadvantages of animal models used for human immunodeficiency virus/human immunodeficiency virusassociated neurocognitive dysfunction study

\begin{tabular}{|c|c|c|}
\hline Model & Advantages & Disadvantages \\
\hline $\begin{array}{l}\text { General } \\
\text { mouse/rat }\end{array}$ & $\begin{array}{l}\text { Availability of inbred and genetically engineered strains; well- } \\
\text { known immune system; inexpensive for housing; fast reproduction }\end{array}$ & pecies barrier for natural productive HIV infection \\
\hline $\begin{array}{l}\text { Transgenic } \\
\text { mouse/rat }\end{array}$ & $\begin{array}{l}\text { Presents good pathogenic manifestations of chronic } \\
\text { HIV-I diseases }\end{array}$ & $\begin{array}{l}\text { No active HIV infection and replication; not all HIV genes } \\
\text { included in a single animal }\end{array}$ \\
\hline $\begin{array}{l}\text { Mouse/rat with } \\
\text { chimeric virus }\end{array}$ & $\begin{array}{l}\text { Active virus infection and replication in vivo, with various } \\
\text { hallmark features of HIV-I infection and some brain pathology }\end{array}$ & $\begin{array}{l}\text { gp I60, a key neurotoxic HIV protein, is disabled; virus does } \\
\text { not replicate as actively as natural HIV infection of human cells }\end{array}$ \\
\hline $\begin{array}{l}\text { SCID/human } \\
\text { mouse model }\end{array}$ & $\begin{array}{l}\text { HIV infection in human cells; different HIV strains can be used; } \\
\text { genetically identical animal is possible with cells from the same } \\
\text { donor; less overall cost of use and need less drugs }\end{array}$ & $\begin{array}{l}\text { Lack of macrophages and robust anti-HIV immunity; technically } \\
\text { challenging and time consuming; different physiology from } \\
\text { humans and no real natural HIV infection; limited life span }\end{array}$ \\
\hline FIV models & $\begin{array}{l}\text { Natural infection in cats with an AIDS-like syndrome following a } \\
\text { long incubation time; requires relatively low expense; present HIV/ } \\
\text { AIDS hallmark of CD4+ T lymphocyte depletion; many similarities } \\
\text { of RTs of FIV and HIV }\end{array}$ & $\begin{array}{l}\text { Most HIV nonnucleoside RT inhibitors and protease } \\
\text { inhibitors are not active against FIV; FIV does not use the } \\
\text { CD4 receptor, and infects not only CD4+ T lymphocytes } \\
\text { but also CD8+ T lymphocytes and B lymphocytes }\end{array}$ \\
\hline SIV models & $\begin{array}{l}\text { Nonhuman primates are phylogenetically the closest to humans } \\
\text { with similar immunology and physiology, viral pathogenesis, } \\
\text { and antiviral immune response; long-term viral persistence }\end{array}$ & $\begin{array}{l}\text { HIV cannot be directly used, requiring use of SIV or SHIV } \\
\text { instead; expensive and very limited availability; large size requires } \\
\text { more drugs; significant genetic differences between HIV and SIV }\end{array}$ \\
\hline
\end{tabular}

Abbreviations: AIDS, acquired immunodeficiency virus; CD, cluster of differentiation; GpI60, glycoprotein-I60; FIV, feline immunodeficiency virus; HIV, human immunodeficiency virus; HIV-I, human immunodeficiency virus type-I; RT, reverse transcriptase; SCID, severe combined immunodeficiency; SHIV, simian human immunodeficiency virus; SIV, simian immunodeficiency virus. 
known. Other advantages of using a mouse model include its relatively low cost and its ability to be housed in large numbers in a relatively small facility and reproduce quickly. Indeed, mouse AIDS models with distantly related oncoviruses (eg, murine leukemia virus) have been used in some early drug studies and have demonstrated efficacy of zidovudine and acyclic nucleoside phosphonates. ${ }^{338,339}$ However, mouse cells do not allow productive HIV infection, and HIV replication in mouse cells is generally disappointing. Blocks at viral entry ${ }^{340}$ and postentry ${ }^{341,342}$ are identified, and the HIV regulator of virion expression and Tat proteins are found to be less functional in mouse cells. ${ }^{343,344}$ Although engineered rats with human CD4, CCR5, and cyclin T1 support some HIV expression, additional obstacles for efficient viral replication and dissemination remain. ${ }^{345,346}$ For these reasons, transgenic rodents with specific HIV genes are produced to model select pathogenic manifestations of chronic HIV-1 diseases. Expression of the HIV gp120 protein in the CNS of a mouse model by astrocytes is the first model of its kind, ${ }^{347}$ and a genetic knockout mouse model of the two major HIV coreceptors, CXCR4 and CCR5, is created, ${ }^{348}$ with the latter model providing an in vivo system for further understanding of the CCR5-mediated pathway. A critical role of CCR5 is found for gp120-induced neuropathogenesis, which supports the indirect toxicity of HIV or viral proteins on neurons and corroborates other studies in linking neuropathogenic effects of HIV to chemokines and their receptors. ${ }^{31,349,350}$ Another transgenic mouse model with the HIV-1 Tat protein has been developed. ${ }^{351}$ Studies using this model have demonstrated that Tat expression in the absence of HIV-1 infection is sufficient to cause neuropathologies similar to most of those noted in the CNS of AIDS patients. It provides the first evidence in the context of a whole organism to support a critical role of the Tat protein in HIV-1 neuropathogenesis, and suggests that the doxycycline-inducible, brain-targeted Tat transgenic mice may offer an in vivo model for delineating the molecular mechanisms of Tat neurotoxicity and for developing novel therapeutic strategies for treating HAND. Another newer transgenic mouse model, in which the HIV Vpr protein is expressed in myeloid cells including those in the CNS and peripheral nervous system, has been developed. ${ }^{59,150}$ A transgenic mouse of this model manifests both structural and functional CNS abnormalities, as well as signs of peripheral neuropathy, and it links the peripheral neuropathy to effects on mitochondria. ${ }^{352}$ More importantly, studies using this model have examined the role of coinfection with hepatitis C virus - common in HIV-infected individuals including those with neurological complications of AIDS - through direct CNS injection of hepatitis C viral proteins, and revealed additional neuronal damage.

A transgenic rat model, with a group-specific antigenpolymerase-deleted HIV-1 genome expressed in many tissues including the CNS, ${ }^{353}$ is created and used to examine the interactions with drugs of abuse, specifically opiates. ${ }^{354}$ Study using this model have identified a wide range of interactions between the virus, host response, and the morphine receptor and its ligands in a preferred behavioral model for drug abuse. ${ }^{355}$ Besides transgenic models, direct injection of viral proteins into the brain has been studied. ${ }^{356}$ Except for the injection of the HIV Tat protein as the main model, effects of an additional injection of neuroprotective molecules, use of transgenic models and chemical inhibitors for mechanistic studies, and the monocyte migration into the brain under the influence of cocaine have been investigated. ${ }^{357}$

To circumvent the species barrier to HIV in rodents, two rodent models using a chimeric virus are developed. The chimeric HIV virus is constructed through the use of a murine retrovirus envelope, which enables the infection of mouse cells including in vivo infection. ${ }^{358,359}$ This model is used to examine the antiviral immune response, by examining resistance to reinfection both peripherally and in the CNS, and shows the role of CD8+ T-cells in transferring immunity, indicating the potential utility of this model in studying host response and protective factors.

Moreover, nontransgenic models, eg, severe combined immunodeficiency (SCID)/human mouse, have been created. These models are produced through transplanting human transplants of thymus, fetal liver, or peripheral blood mononuclear cell into SCID mice. ${ }^{360,361}$ Although immune cells in the implanted human tissues allow reconstitution of the immune system of the SCID mice, most of these models have a limited repertoire of human cell types and limited distribution of the immune cells outside of the implant. ${ }^{336}$ Another similar model with humanized bone marrow/ liver/thymus has better systemic reconstitution of all major human hematopoietic lineages, including T/B-lymphocytes, monocytes/macrophages, dendritic cells, and natural killer cells. ${ }^{362}$ Furthermore, a Trimera mouse model, by engrafting human peripheral blood lymphocytes in normal strains of mice, is used to study human immune responses and may be used for HIV infection as well. In this model, the normal hematopoietic system of the mouse is radiated by split-dose total body irradiation, with the immune system subsequently reconstituted by transplantation of murine SCID bone marrow, converting the normal hematopoietic system into a SCID-like system. The mice are subsequently converted 
to Trimera by intraperitoneal injection of human peripheral blood lymphocytes. ${ }^{363,364}$ These models of a human immune system within an immunodeficient mouse host has enabled HIV infection and the study of many virus/host cell interactions. ${ }^{365}$ Furthermore, inclusion of myeloid cells in HIV neuropathogenesis studies has provided key findings in the effects of HIV on the brain and the science behind them. ${ }^{366,367}$ HIV-infected humanized mice brains are studied through noninvasive imaging studies to examine not only effects of HIV on the brain structure but also key metabolic effects that significantly impact neuronal and overall brain function. ${ }^{368}$ This makes longitudinal analyses for leukocyte migration and brain virus distribution possible, ${ }^{369}$ which are especially important in the current cART era of HIV infection.

Whilst these rodent models are useful as initial in vivo screening methods for antiviral strategies, their disadvantages are that they remain technically challenging and timeconsuming, they do not recapitulate the full spectrum of immunopathological events that occur during natural HIV infection, and their physiology remains quite different from that of humans. ${ }^{336}$

\section{FIV models}

FIV is another lentivirus that infects domestic cats and develops an AIDS-like syndrome following a long incubation period. ${ }^{370}$ This has several advantages for modeling HIVassociated diseases including that it is a natural infection model, it requires relatively low expense, and cats experience a CD4+ T-cell depletion during the course of pathogenesis which is a hallmark of HIV/AIDS. Additionally, RTs of FIV and HIV have many similarities in sequence, function, and in vitro sensitivity to nucleoside RT inhibitors such as zidovudine, lamivudine, didanosine and the nucleotide RT inhibitor adefovir, ${ }^{371-376}$ except that most nonnucleoside RT inhibitors and protease inhibitors are not active against FIV. ${ }^{377}$ Following primary infection, the relatively long asymptomatic period before the onset of disease makes FIV an attractive model for the study of effects of chronic infection. Using a synthetic ligand of a neurotrophin receptor, neuroprotection is demonstrated in vitro in an FIV/feline neural culture system. ${ }^{314}$ However, despite the advantages of the FIV model as an early screening method, several factors have made it less popular than the nonhuman primate models. These factors include FIV not using the CD4 receptor and infecting not only CD4+ T-cells but also CD8+ T-cells and B-cells. ${ }^{378}$ In addition, the long incubation period is a disadvantage in screening the efficacy of drugs.

\section{SIV models}

Whilst the rodent and feline models have their advantages for initial screening, further testing/confirmation is best done in nonhuman primate models that are closer to the HIV infection of humans, which allows a more reliable extrapolation of the results. Nonhuman primates are phylogenetically the closest to humans, and have similar immunology and physiology. However, direct use of HIV-1 is limited by various factors. Although chimpanzees are susceptible to infection with HIV-1, they are limited by the low availability, high price, ethical issues, and the observation that disease rarely develops following infection. ${ }^{379-381}$ Whilst HIV-1 infection can be induced in young pigtailed macaques, virus replication cannot last a long time and no disease was observed. ${ }^{382}$ Substitution of the viral infectivity factor protein with viral infectivity factor from pathogenic SIV enables replication of HIV-1 in pig-tailed macaque T-cells in vitro and results in acute viremia that approaches the levels observed in HIV-1infected humans, significantly extending persistent infection for several months in vivo. ${ }^{383,384}$ However, additional adaptation of the virus may still be necessary to enhance viral replication. ${ }^{383}$ HIV-2 infection models have been developed with Hamadryas baboons and several macaque species. Depending on the HIV-2 isolates, the outcome varies from an AIDS-like disease with CD4+ T-cell decline to no disease. ${ }^{385-387}$

Other than HIV, many nonhuman primate species in Africa are naturally infected with SIV strains, such as African green monkeys and sooty mangabeys. These viruses are closely related to HIV-2. However, probably because viral infections lead to little activation of the immune cells, these hosts rarely develop disease in spite of persistent high-level virus replication. ${ }^{388-390}$ In contrast, SIV infection of nonnatural hosts, such as Asian monkeys like rhesus and pigtailed macaques, tends to follow a similar disease course as human AIDS in many aspects, ${ }^{391,392}$ including cell tropism, generalized immune activation, CD4+ T-cell depletion, opportunistic infections, weight loss, and wasting. ${ }^{393,394}$ Furthermore, similar to the HIV-1 infection in humans, the same clinical and laboratory markers, eg, viral RNA levels in plasma and CD4+ T-cell counts, can be used to monitor and predict disease progression. ${ }^{395-397}$

On the other hand, although SIV is closely related to HIV-1, significant genetic differences between them exist, resulting in distinct adaptive strengths, weaknesses, and peculiarities, as well as functional consequences. These differences make it difficult to study their effects on pathogenesis or their targeting by drugs. ${ }^{398}$ In order to overcome 
these limitations, various SIV/HIV chimeric viruses (SHIVs) that more closely represent HIV-1 have been constructed and used in many macaque experiments. The first SHIV is an $\mathrm{SIV}_{\mathrm{MAC}}$ chimera containing the tat, rev, vpu, and env genes from HIV-1. ${ }^{399}$ This virus replicates and causes disease in animals, ${ }^{400-402}$ and many versions of this type of SHIV have been made thereafter. Although the most extensively studied SHIVs are made from X4-tropic HIV-1, ${ }^{401,403}$ SHIVs with incorporation of the R5-tropic HIV-1 envelopes have been developed. ${ }^{404-406}$ Because most primary HIV-1 isolates are R5 tropic, these SHIVs are more valuable to studies of early HIV-1 infection and pathogenesis, as well as mucosal transmission..$^{407-409}$ Because many HIV-1 RT inhibitors do not inhibit SIV RT, ${ }^{410,411}$ SIV RT is replaced with the HIV-1 RT and used for in vivo drug studies. ${ }^{410-412}$ For similar reasons, another SHIV with HIV-1-derived protease is constructed, ${ }^{413}$ making it a useful tool for in vivo efficacy tests of protease inhibitors. Animal models based on these SHIVs have greatly advanced HIV-1 research and are useful adjuncts to the SIV model.

Despite limitations of the SIV-macaque models, the similarities in virus, host, and disease pathogenesis have made them currently the premier animal model in HIV research, with many therapeutic agents and functions able to be assessed in monkeys using experimental protocols that cannot be done in humans. A rapid model of the neurological complications of AIDS in rhesus macaques is developed by depletion of CD8+ T-cells via antibody treatment at the time of infection with SIV, ${ }^{414,415}$ leading to altered neurological conditions with a high proportion of animals developing SIV encephalitis. This model is applicable for studying monocyte/macrophage imaging, trafficking, turnover, and linked biomarkers of disease, as well as understanding the key mechanisms of neuropathogenesis and its potential prevention and treatment through the application of experimental and therapeutic modalities. SIV-infected pigtailed macaques are used to study the effects of cocaine abuse on HIV pathogenesis, ${ }^{416}$ but few differences attributable to cocaine administration have been found, despite extensive studies being performed on virological, neuroinflammatory, and behavioral parameters. This suggests that cocaine has no distinct effect on SIV in the brain. Furthermore, characterization of the brain transcriptome in SIV-infected rhesus monkeys can be studied through the use of bioinformatics, with altered pathways found at different stages of infection, ${ }^{417}$ and a subset of altered messenger RNAs and microRNAs have been commonly identified in studies comparing SIV and HIV encephalitis. ${ }^{418}$

\section{Conclusion}

The HIV infection pandemic has proved a unique and difficult challenge. Infection by HIV causes neuronal dysfunction and loss of numerous interplaying mechanisms. It has become clear that HAND results from a complex interaction of effects caused by viral proteins and host inflammatory mediators. This article is a summary of current evidence that supports either the direct or indirect mechanisms by which neuronal death may occur during HIV infection. From the literature and ongoing studies, it is clear that a considerable amount of further investigations are still necessary to elucidate the mechanisms of HIV neurotoxicity and the pathogenesis of HAND. Understanding these mechanisms is tantamount to the development of therapeutics that would attenuate or prevent the neuronal degeneration associated with late-stage HIV infection.

Although cART has markedly reduced the morbidity and mortality of HIV-caused neurological diseases and the severe cognitive and motor dysfunctions of HAND, as well as the sensory neuropathies, HAND remains common in the cART era, with up to half of HIV-1 patients affected. ${ }^{22,248}$ Part of the reason that current $\mathrm{cART}$ regimens are inadequate in providing complete protection from developing these neurological complications or eradication of HIV in the CNS is due to poor penetration of these drugs. With future development of improved systems for the delivery of drugs, or drugs with improved capability of penetrating BBB, cART regimens may play a more significant role in the treatment of HIV infection and its progression to neurological disease.

Since the discovery of HIV, despite many initial obstacles, the development of animal models for HIV infection has evolved dramatically. However, each of the available models has its intrinsic limitations and advantages. In spite of their limitations, these models have provided unique and valuable tools for studies addressing specific issues. Further development of novel models and refinement of the current ones to more accurately reflect the biological properties and physiological conditions of HIV infection of humans are required for the effective management of therapeutic strategies and the development of novel anti-HIV therapeutics.

\section{Disclosure}

The authors report no conflicts of interest in this work.

\section{References}

1. Douek DC, Roederer M, Koup RA. Emerging concepts in the immunopathogenesis of AIDS. Annu Rev Med. 2009;60:471-484.

2. Joint United Nations Program on HIV/AIDS. Report on the Global AIDS Epidemic 2006. Geneva: UNAIDS; 2006. 
3. Joint United Nations Program on HIV/AIDS. Report on the Global AIDS Epidemic 2010. Geneva: UNAIDS; 2010.

4. Cunningham AL, Donaghy H, Harman AN, Kim M, Turville SG. Manipulation of dendritic cell function by viruses. Curr Opin Microbiol. 2010;13(4):524-529.

5. Migueles SA, Connors M. Long-term nonprogressive disease among untreated HIV-infected individuals: clinical implications of understanding immune control of HIV. JAMA. 2010;304(2):194-201.

6. Gray F, Adle-Biassette H, Chretien F, Lorin de la Grandmaison G, Force G, Keohane C. Neuropathology and neurodegeneration in human immunodeficiency virus infection. Pathogenesis of HIV-induced lesions of the brain, correlations with HIV-associated disorders and modifications according to treatments. Clin Neuropathol. 2001;20(4): $146-155$.

7. Gonzalez RG, Cheng LL, Westmoreland SV, et al. Early brain injury in the SIV-macaque model of AIDS. AIDS. 2000;14(18): 2841-2849.

8. Powderly WG. Current approaches to treatment for HIV-1 infection. J Neurovirol. 2000;6(Suppl 1):S8-S13.

9. McArthur JC, Brew BJ, Nath A. Neurological complications of HIV infection. Lancet Neurol. 2005;4(9):543-555.

10. Jones G, Power C. Regulation of neural cell survival by HIV-1 infection. Neurobiol Dis. 2006;21(1):1-17.

11. Kaul M, Garden GA, Lipton SA. Pathways to neuronal injury and apoptosis in HIV-associated dementia. Nature. 2001;410(6831):988-994.

12. Kaul M, Zheng J, Okamoto S, Gendelman HE, Lipton SA. HIV-1 infection and AIDS: consequences for the central nervous system. Cell Death Differ. 2005;12(Suppl 1):S878-S892.

13. Kramer-Hammerle S, Rothenaigner I, Wolff H, Bell JE, Brack-Werner R. Cells of the central nervous system as targets and reservoirs of the human immunodeficiency virus. Virus Res. 2005;111(2):194-213.

14. Lavi E, Kolson DL, Ulrich AM, Fu L, Gonzalez-Scarano F. Chemokine receptors in the human brain and their relationship to HIV infection. J Neurovirol. 1998;4(3):301-311.

15. Miller RJ, Meucci O. AIDS and the brain: is there a chemokine connection? Trends Neurosci. 1999;22(10):471-479.

16. Minghetti L. Role of inflammation in neurodegenerative diseases. Curr Opin Neurol. 2005;18(3):315-321.

17. Everall IP, Hansen LA, Masliah E. The shifting patterns of HIV encephalitis neuropathology. Neurotox Res. 2005;8(1-2):51-61.

18. James HJ, Sharer LR, Zhang Q, et al. Expression of caspase-3 in brains from paediatric patients with HIV-1 encephalitis. Neuropathol Appl Neurobiol. 1999;25(5):380-386.

19. Masliah E, DeTeresa RM, Mallory ME, Hansen LA. Changes in pathological findings at autopsy in AIDS cases for the last 15 years. AIDS. 2000;14(1):69-74.

20. Antinori A, Arendt G, Becker JT, et al. Updated research nosology for HIV-associated neurocognitive disorders. Neurology. 2007;69(18): 1789-1799.

21. McArthur JC, Steiner J, Sacktor N, Nath A. Human immunodeficiency virus-associated neurocognitive disorders: mind the gap. Ann Neurol. 2010;67(6):699-714.

22. Heaton RK, Franklin DR, Ellis RJ, et al. HIV-associated neurocognitive disorders before and during the era of combination antiretroviral therapy: differences in rates, nature, and predictors. $J$ Neurovirol. 2011;17(1):3-16.

23. Heaton RK, Clifford DB, Franklin DR Jr, et al. HIV-associated neurocognitive disorders persist in the era of potent antiretroviral therapy: CHARTER Study. Neurology. 2010;75(23):2087-2096.

24. Bhaskaran K, Mussini C, Antinori A, et al. Changes in the incidence and predictors of human immunodeficiency virus-associated dementia in the era of highly active antiretroviral therapy. Ann Neurol. 2008;63(2): 213-221.

25. Lescure FX, Omland LH, Engsig FN, et al. Incidence and impact on mortality of severe neurocognitive disorders in persons with and without HIV infection: a Danish nationwide cohort study. Clin Infect Dis. 2011;52(2):235-243.
26. McArthur JC, Hoover DR, Bacellar H, et al. Dementia in AIDS patients: incidence and risk factors. Multicenter AIDS Cohort Study. Neurology. 1993;43(11):2245-2252.

27. Chakravarty S, Herkenham M. Toll-like receptor 4 on nonhematopoietic cells sustains CNS inflammation during endotoxemia, independent of systemic cytokines. J Neurosci. 2005;25(7):1788-1796.

28. Turrin NP, Rivest S. Unraveling the molecular details involved in the intimate link between the immune and neuroendocrine systems. Exp Biol Med (Maywood). 2004;229(10):996-1006.

29. Cunningham PH, Smith DG, Satchell C, Cooper DA, Brew B. Evidence for independent development of resistance to HIV-1 reverse transcriptase inhibitors in the cerebrospinal fluid. AIDS. 2000;14(13):1949-1954.

30. Hesselgesser J, Taub D, Baskar P, et al. Neuronal apoptosis induced by HIV-1 gp120 and the chemokine SDF-1 alpha is mediated by the chemokine receptor CXCR4. Curr Biol. 1998;8(10):595-598.

31. Kaul M, Ma Q, Medders KE, Desai MK, Lipton SA. HIV-1 coreceptors CCR5 and CXCR4 both mediate neuronal cell death but CCR5 paradoxically can also contribute to protection. Cell Death Differ. 2007; 14(2):296-305.

32. Bunnik EM, Swenson LC, Edo-Matas D, et al. Detection of inferred CCR5- and CXCR4-using HIV-1 variants and evolutionary intermediates using ultra-deep pyrosequencing. PLoS Pathog. 2011; 7(6):e1002106.

33. Lazarini F, Tham TN, Casanova P, Arenzana-Seisdedos F, DuboisDalcq M. Role of the alpha-chemokine stromal cell-derived factor (SDF-1) in the developing and mature central nervous system. Glia. 2003;42(2):139-148.

34. van der Meer P, Ulrich AM, Gonzalez-Scarano F, Lavi E. Immunohistochemical analysis of CCR2, CCR3, CCR5, and CXCR4 in the human brain: potential mechanisms for HIV dementia. Exp Mol Pathol. 2000;69(3):192-201.

35. Meucci O, Fatatis A, Simen AA, Bushell TJ, Gray PW, Miller RJ. Chemokines regulate hippocampal neuronal signaling and gp120 neurotoxicity. Proc Natl Acad Sci U S A. 1998;95(24):14500-14505.

36. Kaul M, Lipton SA. Chemokines and activated macrophages in HIV gp120-induced neuronal apoptosis. Proc Natl Acad Sci U S A. 1999; 96(14):8212-8216.

37. Kruman II, Nath A, Mattson MP. HIV-1 protein Tat induces apoptosis of hippocampal neurons by a mechanism involving caspase activation, calcium overload, and oxidative stress. Exp Neurol. 1998;154(2) :276-288

38. McArthur JC. HIV dementia: an evolving disease. $J$ Neuroimmunol. 2004;157(1-2):3-10.

39. Choi WT, Kaul M, Kumar S, et al. Neuronal apoptotic signaling pathways probed and intervened by synthetically and modularly modified (SMM) chemokines. J Biol Chem. 2007;282(10):7154-7163.

40. Brooks JT, Kaplan JE, Masur H. What's new in the 2009 US guidelines for prevention and treatment of opportunistic infections among adults and adolescents with HIV? Top HIV Med. 2009;17(3):109-114.

41. McArthur JC. Neurologic manifestations of AIDS. Medicine (Baltimore). 1987;66(6):407-437.

42. Glass JD, Wesselingh SL. Microglia in HIV-associated neurological diseases. Microsc Res Tech. 2001;54(2):95-105.

43. Langford TD, Letendre SL, Larrea GJ, Masliah E. Changing patterns in the neuropathogenesis of HIV during the HAART era. Brain Pathol. 2003;13(2):195-210.

44. Kraft-Terry SD, Stothert AR, Buch S, Gendelman HE. HIV-1 neuroimmunity in the era of antiretroviral therapy. Neurobiol Dis. 2010; 37(3):542-548.

45. Johnson T, Nath A. Neurological complications of immune reconstitution in HIV-infected populations. Ann N Y Acad Sci. 2010; 1184:106-120.

46. French MA. HIV/AIDS: immune reconstitution inflammatory syndrome: a reappraisal. Clin Infect Dis. 2009;48(1):101-107.

47. Miller RF, Isaacson PG, Hall-Craggs M, et al. Cerebral CD8+ lymphocytosis in HIV-1 infected patients with immune restoration induced by HAART. Acta Neuropathol. 2004;108:17-23. 
48. Anneken K, Fischera M, Evers S, Kloska S, Husstedt IW. Recurrent vacuolar myelopathy in HIV infection. J Infect. 2006;52(6): e181-e183.

49. Di Rocco A, Simpson DM. AIDS-associated vacuolar myelopathy. AIDS Patient Care STDS. 1998;12(6):457-461.

50. Singer EJ, Valdes-Sueiras M, Commins D, Levine A. Neurologic presentations of AIDS. Neurol Clin. 2010;28(1):253-275.

51. Aboulafia DM, Taylor L. Vacuolar myelopathy and vacuolar cerebellar leukoencephalopathy: a late complication of AIDS after highly active antiretroviral therapy-induced immune reconstitution. AIDS Patient Care STDS. 2002;16(12):579-584.

52. Schmidbauer M, Budka H, Okeda R, Cristina S, Lechi A, Trabattoni GR. Multifocal vacuolar leucoencephalopathy: a distinct HIV-associated lesion of the brain. Neuropathol Appl Neurobiol. 1990;16(5):437-443.

53. Bassiri A, Holden J, Wong M. A case of fulminant human immunodeficiency virus dementia. Clin Infect Dis. 1995;21(5): 1313-1314.

54. Berger JR, Arendt G. HIV dementia: the role of the basal ganglia and dopaminergic systems. J Psychopharmacol. 2000;14(3):214-221.

55. Avison MJ, Nath A, Greene-Avison R, Schmitt FA, Greenberg RN, Berger JR. Neuroimaging correlates of HIV-associated BBB compromise. J Neuroimmunol. 2004;157(1-2):140-146.

56. Newsome SD, Johnson E, Pardo C, McArthur JC, Nath A. Fulminant encephalopathy with basal ganglia hyperintensities in HIV-infected drug users. Neurology. 2011;76(9):787-794.

57. Brinley FJ Jr, Pardo CA, Verma A. Human immunodeficiency virus and the peripheral nervous system workshop. Arch Neurol. 2001;58(10): 1561-1566.

58. Acharjee S, Noorbakhsh F, Stemkowski PL, et al. HIV-1 viral protein $\mathrm{R}$ causes peripheral nervous system injury associated with in vivo neuropathic pain. FASEB J. 2010;24(11):4343-4353.

59. Phillips TJ, Cherry CL, Cox S, Marshall SJ, Rice AS. Pharmacological treatment of painful HIV-associated sensory neuropathy: a systematic review and meta-analysis of randomised controlled trials. PLoS One. 2010;5(12):e14433.

60. Foster C, Lyall H. HIV and mitochondrial toxicity in children. JAntimicrob Chemother. 2008;61(1):8-12.

61. Van der Watt G. Mitochondrial dysfunction and human immunodeficiency virus infection. JEMDSA. 2011;16(2):94-100.

62. Kaplan JE, Benson C, Holmes KH, Brooks JT, Pau A, Masur H. Guidelines for prevention and treatment of opportunistic infections in HIV-infected adults and adolescents: recommendations from CDC, the National Institutes of Health, and the HIV Medicine Association of the Infectious Diseases Society of America. MMWR Recomm Rep. 2009;58(RR-4):1-207.

63. Ferenczy MW, Marshall LJ, Nelson CD, et al. Molecular biology, epidemiology, and pathogenesis of progressive multifocal leukoencephalopathy, the JC virus-induced demyelinating disease of the human brain. Clin Microbiol Rev. 2012;25(3):471-506.

64. Nukuzuma S, Nakamichi K, Kameoka M, et al. Efficient propagation of progressive multifocal leukoencephalopathy-type JC virus in COS-7-derived cell lines stably expressing Tat protein of human immunodeficiency virus type 1. Microbiol Immunol. 2010;54(12): 758-762.

65. Stettner MR, Nance JA, Wright CA, et al. SMAD proteins of oligodendroglial cells regulate transcription of JC virus early and late genes coordinately with the Tat protein of human immunodeficiency virus type 1. J Gen Virol. 2009;90(Pt 8):2005-2014.

66. Daniel DC, Wortman MJ, Schiller RJ, et al. Coordinate effects of human immunodeficiency virus type 1 protein Tat and cellular protein Puralpha on DNA replication initiated at the JC virus origin. J Gen Virol. 2001;82(Pt 7):1543-1553.

67. Giudici B, Vaz B, Bossolasco S, et al. Highly active antiretroviral therapy and progressive multifocal leukoencephalopathy: effects on cerebrospinal fluid markers of JC virus replication and immune response. Clin Infect Dis. 2000;30(1):95-99.
68. Centers for Disease Control and Prevention. HIV infection among injection-drug users - 34 states, 2004-2007. MMWR Morb Mortal Wkly Rep. 2009;58(46):1291-1295.

69. Vlahov D, Robertson AM, Strathdee SA. Prevention of HIV infection among injection drug users in resource-limited settings. Clin Infect Dis. 2010;50(Suppl 3):S114-S121.

70. Rouveix B. Opiates and immune function. Consequences on infectious diseases with special reference to AIDS. Therapie. 1992;47(6): 503-512.

71. Arora PK. Morphine-induced immune modulation: does it predispose to HIV infection? NIDA Res Monogr. 1990;96:150-165.

72. Bell JE, Brettle RP, Chiswick A, Simmonds P. HIV encephalitis, proviral load and dementia in drug users and homosexuals with AIDS. Effect of neocortical involvement. Brain. 1998;121(Pt 11):2043-2052.

73. Bell JE, Arango JC, Robertson R, Brettle RP, Leen C, Simmonds P. HIV and drug misuse in the Edinburgh cohort. J Acquir Immune Defic Syndr. 2002;31(Suppl 2):S35-S42.

74. Arango JC, Simmonds P, Brettle RP, Bell JE. Does drug abuse influence the microglial response in AIDS and HIV encephalitis? AIDS. 2004;18(Suppl 1):S69-S74.

75. Fitting $\mathrm{S}, \mathrm{Xu} \mathrm{R}, \mathrm{Bull} \mathrm{C}$, et al. Interactive comorbidity between opioid drug abuse and HIV-1 Tat: chronic exposure augments spine loss and sublethal dendritic pathology in striatal neurons. Am J Pathol. 2010;177(3):1397-1410.

76. Suzuki M, El-Hage N, Zou S, et al. Fractalkine/CX3CL1 protects striatal neurons from synergistic morphine and HIV-1 Tat-induced dendritic losses and death. Mol Neurodegener. 2011;6:78.

77. Zou S, Fitting S, Hahn YK, et al. Morphine potentiates neurodegenerative effects of HIV-1 Tat through actions at $\mu$-opioid receptor-expressing glia. Brain. 2011;134(Pt 12):3616-3631.

78. Hauser KF, Hahn YK, Adjan VV, et al. HIV-1 Tat and morphine have interactive effects on oligodendrocyte survival and morphology. Glia. 2009;57(2):194-206.

79. Malik S, Khalique H, Buch S, Seth P. A growth factor attenuates HIV-1 Tat and morphine induced damage to human neurons: implication in HIV/AIDS-drug abuse cases. PLoS One. 2011;6(3):e18116.

80. Khurdayan VK, Buch S, El-Hage N, et al. Preferential vulnerability of astroglia and glial precursors to combined opioid and HIV-1 Tat exposure in vitro. Eur J Neurosci. 2004;19(12):3171-3182.

81. Buch SK, Khurdayan VK, Lutz SE, Knapp PE, El-Hage N, Hauser KF. Glial-restricted precursors: patterns of expression of opioid receptors and relationship to human immunodeficiency virus-1 Tat and morphine susceptibility in vitro. Neuroscience. 2007;146(4):1546-1554.

82. Fitting S, Zou S, Chen W, Vo P, Hauser KF, Knapp PE. Regional heterogeneity and diversity in cytokine and chemokine production by astroglia: differential responses to HIV-1 Tat, gp120, and morphine revealed by multiplex analysis. J Proteome Res. 2010;9(4):1795-1804.

83. Colfax G, Shoptaw S. The methamphetamine epidemic: implications for HIV prevention and treatment. Curr HIV/AIDS Rep. 2005;2(4) 194-199.

84. Potula R, Persidsky Y. Adding fuel to the fire: methamphetamine enhances HIV infection. Am J Pathol. 2008;172(6):1467-1470.

85. Liang H, Wang X, Chen H, et al. Methamphetamine enhances HIV infection of macrophages. Am J Pathol. 2008;172(6):1617-1624.

86. Wang X, Wang Y, Ye L, et al. Modulation of intracellular restriction factors contributes to methamphetamine-mediated enhancement of acquired immune deficiency syndrome virus infection of macrophages. Curr HIV Res. 2012;10(5):407-414.

87. Chang L, Ernst T, Speck O, Grob CS. Additive effects of HIV and chronic methamphetamine use on brain metabolite abnormalities. Am J Psychiatry. 2005;162(2):361-369.

88. Degenhardt L, Mathers B, Guarinieri M, et al. Meth/amphetamine use and associated HIV: implications for global policy and public health. Int J Drug Policy. 2010;21(5):347-358.

89. Rippeth JD, Heaton RK, Carey CL, et al. Methamphetamine dependence increases risk of neuropsychological impairment in HIV infected persons. J Int Neuropsychol Soc. 2004;10(1):1-14. 
90. Pendyala G, Buescher JL, Fox HS. Methamphetamine and inflammatory cytokines increase neuronal $\mathrm{Na}+/ \mathrm{K}+$-ATPase isoform 3 : relevance for HIV associated neurocognitive disorders. PLoS One. 2012;7(5):e37604.

91. Blankson JN, Persaud D, Siliciano RF. The challenge of viral reservoirs in HIV-1 infection. Annu Rev Med. 2002;53:557-593.

92. Nath A, Clements JE. Eradication of HIV from the brain: reasons for pause. AIDS. 2011;25(5):577-580.

93. Wong JK, Ignacio CC, Torriani F, Havlir D, Fitch NJ, Richman DD. In vivo compartmentalization of human immunodeficiency virus: evidence from the examination of pol sequences from autopsy tissues. J Virol. 1997;71(3):2059-2071.

94. Zaitseva M, Peden K, Golding H. HIV coreceptors: role of structure, posttranslational modifications, and internalization in viral-cell fusion and as targets for entry inhibitors. Biochim Biophys Acta. 2003; 1614(1):51-61.

95. Gonzalez-Scarano F, Martin-Garcia J. The neuropathogenesis of AIDS. Nat Rev Immunol. 2005;5(1):69-81.

96. Moore JP, Kitchen SG, Pugach P, Zack JA. The CCR5 and CXCR4 coreceptors - central to understanding the transmission and pathogenesis of human immunodeficiency virus type 1 infection. AIDS Res Hum Retroviruses. 2004;20(1):111-126.

97. Schnell G, Joseph S, Spudich S, Price RW, Swanstrom R. HIV-1 replication in the central nervous system occurs in two distinct cell types. PLoS Pathog. 2011;7(10):e1002286.

98. Bagasra O, Lavi E, Bobroski L, et al. Cellular reservoirs of HIV-1 in the central nervous system of infected individuals: identification by the combination of in situ polymerase chain reaction and immunohistochemistry. AIDS. 1996;10(6):573-585.

99. Trkola A. HIV-host interactions: vital to the virus and key to its inhibition. Curr Opin Microbiol. 2004;7(4):407-411.

100. Ranki A, Nyberg M, Ovod V, et al. Abundant expression of HIV Nef and Rev proteins in brain astrocytes in vivo is associated with dementia. AIDS. 1995;9(9):1001-1008.

101. Gorry PR, Ong C, Thorpe J, et al. Astrocyte infection by HIV-1: mechanisms of restricted virus replication, and role in the pathogenesis of HIV-1-associated dementia. Curr HIV Res. 2003;1(4):463-473.

102. Ghafouri M, Amini S, Khalili K, Sawaya BE. HIV-1 associated dementia: symptoms and causes. Retrovirology. 2006;3:28.

103. Gorry P, Purcell D, Howard J, McPhee D. Restricted HIV-1 infection of human astrocytes: potential role of nef in the regulation of virus replication. J Neurovirol. 1998;4(4):377-386.

104. Lawrence DM, Durham LC, Schwartz L, Seth P, Maric D, Major EO. Human immunodeficiency virus type 1 infection of human brainderived progenitor cells. J Virol. 2004;78(14):7319-7328.

105. Oguariri RM, Brann TW, Imamichi T. Hydroxyurea and interleukin-6 synergistically reactivate HIV-1 replication in a latently infected promonocytic cell line via SP1/SP3 transcription factors. J Biol Chem. 2007;282(6):3594-3604.

106. Hoshino S, Konishi M, Mori M, et al. HIV-1 Vpr induces TLR4/ MyD88-mediated IL-6 production and reactivates viral production from latency. J Leukoc Biol. 2010;87(6):1133-1143.

107. Strazza M, Pirrone V, Wigdahl B, Nonnemacher MR. Breaking down the barrier: the effects of HIV-1 on the blood-brain barrier. Brain Res. 2011;1399:96-115.

108. Albright AV, Soldan SS, Gonzalez-Scarano F. Pathogenesis of human immunodeficiency virus-induced neurological disease. J Neurovirol. 2003;9(2):222-227.

109. Wiley CA, Schrier RD, Nelson JA, Lampert PW, Oldstone MB. Cellular localization of human immunodeficiency virus infection within the brains of acquired immune deficiency syndrome patients. Proc Natl Acad Sci U S A. 1986;83(18):7089-7093.

110. Ward JM, O’Leary TJ, Baskin GB, et al. Immunohistochemical localization of human and simian immunodeficiency viral antigens in fixed tissue sections. Am J Pathol. 1987;127(2):199-205.

111. Wiley CA, Nelson JA. Role of human immunodeficiency virus and cytomegalovirus in AIDS encephalitis. Am J Pathol. 1988; 133(1):73-81.
112. Liu NQ, Lossinsky AS, Popik W, et al. Human immunodeficiency virus type 1 enters brain microvascular endothelia by macropinocytosis dependent on lipid rafts and the mitogen-activated protein kinase signaling pathway. J Virol. 2002;76(13):6689-6700.

113. Gras G, Kaul M. Molecular mechanisms of neuroinvasion by monocytes-macrophages in HIV-1 infection. Retrovirology. 2010; $7: 30$.

114. Prospero-Garcia O, Gold LH, Fox HS, et al. Microglia-passaged simian immunodeficiency virus induces neurophysiological abnormalities in monkeys. Proc Natl Acad Sci U S A. 1996;93(24):14158-14163.

115. Kalams SA, Walker BD. Cytotoxic T lymphocytes and HIV-1 related neurologic disorders. Curr Top Microbiol Immunol. 1995;202: 79-88.

116. Mennicken F, Maki R, de Souza EB, Quirion R. Chemokines and chemokine receptors in the CNS: a possible role in neuroinflammation and patterning. Trends Pharmacol Sci. 1999;20(2):73-78.

117. Mercer J, Helenius A. Virus entry by macropinocytosis. Nat Cell Biol. 2009;11(5):510-520.

118. Dohgu S, Banks WA. Lipopolysaccharide-enhanced transcellular transport of HIV-1 across the blood-brain barrier is mediated by the p38 mitogen-activated protein kinase pathway. Exp Neurol. 2008;210(2):740-749

119. Stins MF, Pearce D, Di Cello F, Erdreich-Epstein A, Pardo CA, Sik Kim K. Induction of intercellular adhesion molecule-1 on human brain endothelial cells by HIV-1 gp120: role of CD4 and chemokine coreceptors. Lab Invest. 2003;83(12):1787-1798.

120. Toborek M, Lee YW, Flora G, et al. Mechanisms of the blood-brain barrier disruption in HIV-1 infection. Cell Mol Neurobiol. 2005;25(1): 181-199.

121. Malik M, Chen YY, Kienzle MF, Tomkowicz BE, Collman RG, Ptasznik A. Monocyte migration and LFA-1-mediated attachment to brain microvascular endothelia is regulated by SDF-1 alpha through Lyn kinase. J Immunol. 2008;181(7):4632-4637.

122. Williams DW, Eugenin EA, Calderon TM, Berman JW. Monocyte maturation, HIV susceptibility, and transmigration across the blood brain barrier are critical in HIV neuropathogenesis. J Leukoc Biol. 2012;91(3):401-415.

123. Mayhan WG. Cellular mechanisms by which tumor necrosis factor- $\alpha$ produces disruption of the blood-brain barrier. Brain Res. 2002;927(2): 144-152.

124. Haorah J, Ramirez SH, Floreani N, Gorantla S, Morsey B, Persidsky Y. Mechanism of alcohol-induced oxidative stress and neuronal injury. Free Radic Biol Med. 2008;45(11):1542-1550.

125. Liu Y, Tang XP, McArthur JC, Scott J, Gartner S. Analysis of human immunodeficiency virus type 1 gp160 sequences from a patient with HIV dementia: evidence for monocyte trafficking into brain. J Neurovirol. 2000;6(Suppl 1):S70-S81.

126. Izquierdo-Useros N, Naranjo-Gomez M, Erkizia I, et al. HIV and mature dendritic cells: Trojan exosomes riding the Trojan horse? PLoS Pathog. 2010;6(3):e1000740.

127. Peluso R, Haase A, Stowring L, Edwards M, Ventura P. A Trojan horse mechanism for the spread of visna virus in monocytes. Virology. 1985;147(1):231-236.

128. Georgsson G. Neuropathologic aspects of lentiviral infections. Ann N Y Acad Sci. 1994;724:50-67.

129. Romero IA, Prevost MC, Perret E, et al. Interactions between brain endothelial cells and human T-cell leukemia virus type 1-infected lymphocytes: mechanisms of viral entry into the central nervous system. J Virol. 2000;74(13):6021-6030.

130. Schouten J, Cinque P, Gisslen M, Reiss P, Portegies P. HIV-1 infection and cognitive impairment in the cART era: a review. AIDS. 2011;25(5): $561-575$.

131. Gartner S. HIV infection and dementia. Science. 2000;287(5453): 602-604.

132. Zheng J, Thylin MR, Persidsky Y, et al. HIV-1 infected immune competent mononuclear phagocytes influence the pathways to neuronal demise. Neurotox Res. 2001;3(5):461-484. 
133. Adamson DC, Kopnisky KL, Dawson TM, Dawson VL. Mechanisms and structural determinants of HIV-1 coat protein, gp41-induced neurotoxicity. J Neurosci. 1999;19(1):64-71.

134. Johnston JB, Zhang K, Silva C, et al. HIV-1 Tat neurotoxicity is prevented by matrix metalloproteinase inhibitors. Ann Neurol. 2001;49(2):230-241.

135. Wallace DR. HIV neurotoxicity: potential therapeutic interventions. J Biomed Biotechnol. 2006;2006(3):1-10.

136. Hult B, Chana G, Masliah E, Everall I. Neurobiology of HIV. Int Rev Psychiatry. 2008;20(1):3-13.

137. Kanmogne GD, Kennedy RC, Grammas P. HIV-1 gp120 proteins and gp160 peptides are toxic to brain endothelial cells and neurons: possible pathway for HIV entry into the brain and HIV-associated dementia. J Neuropathol Exp Neurol. 2002;61(11):992-1000.

138. Hesselgesser J, Halks-Miller M, DelVecchio V, et al. CD4independent association between HIV-1 gp120 and CXCR4: functional chemokine receptors are expressed in human neurons. Curr Biol. 1997;7(2):112-121

139. Cao S, Wu C, Yang Y, et al. Lentiviral vector-mediated stable expression of sTNFR-Fc in human macrophage and neuronal cells as a potential therapy for neuroAIDS. J Neuroinflammation. 2011;8:48.

140. Zheng J, Thylin MR, Ghorpade A, et al. Intracellular CXCR4 signaling, neuronal apoptosis and neuropathogenic mechanisms of HIV-1associated dementia. J Neuroimmunol. 1999;98(2):185-200.

141. Meucci O, Fatatis A, Simen AA, Miller RJ. Expression of CX3CR1 chemokine receptors on neurons and their role in neuronal survival. Proc Natl Acad Sci U S A. 2000;97(14):8075-8080.

142. Chen L, Liu J, Xu C, Keblesh J, Zang W, Xiong H. HIV-1 gp120 induces neuronal apoptosis through enhancement of 4-aminopyridine-senstive outward K+ currents. PLoS One. 2011;6(10):e25994.

143. Fontana G, Valenti L, Raiteri M. Gp120 can revert antagonism at the glycine site of NMDA receptors mediating GABA release from cultured hippocampal neurons. J Neurosci Res. 1997;49(6):732-738.

144. Chen W, Tang Z, Fortina P, et al. Ethanol potentiates HIV-1 gp120induced apoptosis in human neurons via both the death receptor and NMDA receptor pathways. Virology. 2005;334(1):59-73.

145. Brown GC, Bal-Price A. Inflammatory neurodegeneration mediated by nitric oxide, glutamate, and mitochondria. Mol Neurobiol. 2003;27(3): 325-355.

146. Liu Y, Jones M, Hingtgen CM, et al. Uptake of HIV-1 tat protein mediated by low-density lipoprotein receptor-related protein disrupts the neuronal metabolic balance of the receptor ligands. Nat Med. 2000;6(12):1380-1387.

147. Nath A, Haughey NJ, Jones M, Anderson C, Bell JE, Geiger JD. Synergistic neurotoxicity by human immunodeficiency virus proteins Tat and gp120: protection by memantine. Ann Neurol. 2000;47(2): 186-194.

148. Prendergast MA, Rogers DT, Mulholland PJ, et al. Neurotoxic effects of the human immunodeficiency virus type-1 transcription factor Tat require function of a polyamine sensitive-site on the N-methyl-Daspartate receptor. Brain Res. 2002;954(2):300-307.

149. Smith DG, Guillemin GJ, Pemberton L, et al. Quinolinic acid is produced by macrophages stimulated by platelet activating factor, Nef and Tat. J Neurovirol. 2001;7(1):56-60.

150. Jones GJ, Barsby NL, Cohen EA, et al. HIV-1 Vpr causes neuronal apoptosis and in vivo neurodegeneration. J Neurosci. 2007;27(14): 3703-3711.

151. Piller SC, Jans P, Gage PW, Jans DA. Extracellular HIV-1 virus protein $R$ causes a large inward current and cell death in cultured hippocampal neurons: implications for AIDS pathology. Proc Natl Acad Sci USA. 1998;95(8):4595-4600.

152. Kaul M, Lipton SA. Mechanisms of neuronal injury and death in HIV-1 associated dementia. Curr HIV Res. 2006;4(3):307-318.

153. Lisi L, Tramutola A, De Luca A, Navarra P, Dello Russo C. Modulatory effects of the CCR5 antagonist maraviroc on microglial pro-inflammatory activation elicited by gp120. J Neurochem. 2012 ; 120(1):106-114.
154. Agrawal L, Louboutin JP, Reyes BA, Van Bockstaele EJ, Strayer DS. HIV-1 Tat neurotoxicity: a model of acute and chronic exposure, and neuroprotection by gene delivery of antioxidant enzymes. Neurobiol Dis. 2012;45(2):657-670.

155. Bezzi P, Domercq M, Brambilla L, et al. CXCR4-activated astrocyte glutamate release via TNFalpha: amplification by microglia triggers neurotoxicity. Nat Neurosci. 2001;4(7):702-710.

156. Yang Y, Yao H, Lu Y, Wang C, Buch S. Cocaine potentiates astrocyte toxicity mediated by human immunodeficiency virus (HIV-1) protein gp120. PLoS One. 2010;5(10):e13427.

157. Nath A, Conant K, Chen P, Scott C, Major EO. Transient exposure to HIV-1 Tat protein results in cytokine production in macrophages and astrocytes. A hit and run phenomenon. J Biol Chem. 1999;274(24): 17098-17102.

158. Dugas N, Lacroix C, Kilchherr E, Delfraissy JF, Tardieu M. Role of CD23 in astrocytes inflammatory reaction during HIV-1 related encephalitis. Cytokine. 2001;15(2):96-107.

159. Gorry PR, Taylor J, Holm GH, et al. Increased CCR5 affinity and reduced CCR5/CD4 dependence of a neurovirulent primary human immunodeficiency virus type 1 isolate. J Virol. 2002;76(12): 6277-6292.

160. Kaul M, Ma Q, Medders KE, Desai MK, Lipton SA. HIV-1 coreceptors CCR5 and CXCR4 both mediate neuronal cell death but CCR5 paradoxically can also contribute to protection. Cell Death Differ. 2007;14(2):296-305

161. Scaravilli F, Bazille C, Gray F. Neuropathologic contributions to understanding AIDS and the central nervous system. Brain Pathol. 2007;17(2):197-208.

162. Lawrence DM, Major EO. HIV-1 and the brain: connections between HIV-1-associated dementia, neuropathology and neuroimmunology. Microbes Infect. 2002;4(3):301-308.

163. Glass JD, Fedor H, Wesselingh SL, McArthur JC. Immunocytochemical quantitation of human immunodeficiency virus in the brain: correlations with dementia. Ann Neurol. 1995;38(5):755-762.

164. Masliah E, Heaton RK, Marcotte TD, et al; HIV Neurobehavioral Research Center. Dendritic injury is a pathological substrate for human immunodeficiency virus-related cognitive disorders. 1997;42(6): 963-972.

165. Xu J, Ikezu T. The comorbidity of HIV-associated neurocognitive disorders and Alzheimer's disease: a foreseeable medical challenge in post-HAART era. J Neuroimmune Pharmacol. 2009;4(2):200-212.

166. Cook-Easterwood J, Middaugh LD, Griffin WC 3rd, Khan I, Tyor WR. Highly active antiretroviral therapy of cognitive dysfunction and neuronal abnormalities in SCID mice with HIV encephalitis. Exp Neurol. 2007;205(2):506-512.

167. Rostasy K, Monti L, Lipton SA, Hedreen JC, Gonzalez RG, Navia BA HIV leucoencephalopathy and TNFalpha expression in neurones. J Neurol Neurosurg Psychiatry. 2005;76(7):960-964.

168. Ownby RL, Kumar AM, Benny Fernandez J, et al. Tumor necrosis factor-alpha levels in HIV-1 seropositive injecting drug users. J Neuroimmune Pharmacol. 2009;4(3):350-358.

169. Airoldi M, Bandera A, Trabattoni D, et al. Neurocognitive impairment in HIV-infected naive patients with advanced disease: the role of virus and intrathecal immune activation. Clin Dev Immunol. 2012;2012:467154.

170. Jiang ZG, Piggee C, Heyes MP, et al. Glutamate is a mediator of neurotoxicity in secretions of activated HIV-1-infected macrophages. J Neuroimmunol. 2001;117(1-2):97-107.

171. Kandanearatchi A, Brew BJ. The kynurenine pathway and quinolinic acid: pivotal roles in HIV associated neurocognitive disorders. FEBS J. 2012;279(8):1366-1374.

172. Gelman BB, Nguyen TP. Synaptic proteins linked to HIV-1 infection and immunoproteasome induction: proteomic analysis of human synaptosomes. J Neuroimmune Pharmacol. 2010;5(1):92-102.

173. Lu SM, Tremblay ME, King IL, et al. HIV-1 Tat-induced microgliosis and synaptic damage via interactions between peripheral and central myeloid cells. PLoS One. 2011;6(9):e23915. 
174. Fox L, Alford M, Achim C, Mallory M, Masliah E. Neurodegeneration of somatostatin-immunoreactive neurons in HIV encephalitis. J Neuropathol Exp Neurol. 1997;56(4):360-368.

175. Harezlak J, Buchthal S, Taylor M, et al. Persistence of HIVassociated cognitive impairment, inflammation, and neuronal injury in era of highly active antiretroviral treatment. AIDS. 2011;25(5): 625-633.

176. Adle-Biassette H, Levy Y, Colombel M, et al. Neuronal apoptosis in HIV infection in adults. Neuropathol Appl Neurobiol. 1995;21(3): 218-227.

177. Gelbard HA, James HJ, Sharer LR, et al. Apoptotic neurons in brains from paediatric patients with HIV-1 encephalitis and progressive encephalopathy. Neuropathol Appl Neurobiol. 1995;21(3): 208-217.

178. Petito CK, Roberts B. Evidence of apoptotic cell death in HIV encephalitis. Am J Pathol. 1995;146(5):1121-1130.

179. Adle-Biassette H, Chretien F, Wingertsmann L, et al. Neuronal apoptosis does not correlate with dementia in HIV infection but is related to microglial activation and axonal damage. Neuropathol Appl Neurobiol. 1999;25(2):123-133.

180. Tyor WR, Wesselingh SL, Griffin JW, McArthur JC, Griffin DE. Unifying hypothesis for the pathogenesis of HIV-associated dementia complex, vacuolar myelopathy, and sensory neuropathy. J Acquir Immune Defic Syndr Hum Retrovirol. 1995;9(4):379-388.

181. Xing HQ, Moritoyo T, Mori K, Sugimoto C, Ono F, Izumo S. Expression of proinflammatory cytokines and its relationship with virus infection in the brain of macaques inoculated with macrophagetropic simian immunodeficiency virus. Neuropathology. 2009;29(1): 13-19.

182. Salomoni P, Cossarizza A. HIV: no PUMA no death? Cell Death Differ. 2004;11(7):691-692.

183. Bissel SJ, Wang G, Bonneh-Barkay D, et al. Systemic and brain macrophage infections in relation to the development of simian immunodeficiency virus encephalitis. J Virol. 2008;82(10): 5031-5042.

184. Yadav A, Collman RG. CNS inflammation and macrophage/microglial biology associated with HIV-1 infection. J Neuroimmune Pharmacol. 2009;4(4):430-447.

185. Valcour VG, Shiramizu BT, Shikuma CM. HIV DNA in circulating monocytes as a mechanism to dementia and other HIV complications. J Leukoc Biol. 2010;87(4):621-626.

186. Rumbaugh JA, Nath A. Developments in HIV neuropathogenesis. Curr Pharm Des. 2006;12(9):1023-1044.

187. Vallat-Decouvelaere AV, Chretien F, Gras G, Le Pavec G, Dormont D, Gray F. Expression of excitatory amino acid transporter-1 in brain macrophages and microglia of HIV-infected patients. A neuroprotective role for activated microglia? J Neuropathol Exp Neurol. 2003;62(5): 475-485.

188. Gras G, Chretien F, Vallat-Decouvelaere AV, et al. Regulated expression of sodium-dependent glutamate transporters and synthetase: a neuroprotective role for activated microglia and macrophages in HIV infection? Brain Pathol. 2003;13(2):211-222.

189. Sippy BD, Hofman FM, Wallach D, Hinton DR. Increased expression of tumor necrosis factor-alpha receptors in the brains of patients with AIDS. J Acquir Immune Defic Syndr Hum Retrovirol. 1995;10(5): 511-521.

190. Tyor WR, Glass JD, Griffin JW, et al. Cytokine expression in the brain during the acquired immunodeficiency syndrome. Ann Neurol. 1992; 31(4):349-360.

191. Turchan-Cholewo J, Dimayuga VM, Gupta S, Gorospe RM, Keller JN, Bruce-Keller AJ. NADPH oxidase drives cytokine and neurotoxin release from microglia and macrophages in response to HIV-Tat. Antioxid Redox Signal. 2009;11(2):193-204.

192. Pais TF, Figueiredo C, Peixoto R, Braz MH, Chatterjee S. Necrotic neurons enhance microglial neurotoxicity through induction of glutaminase by a MyD88-dependent pathway. J Neuroinflammation. 2008;5:43.
193. Robinson AP, White TM, Mason DW. Macrophage heterogeneity in the rat as delineated by two monoclonal antibodies MRC OX-41 and MRC OX-42, the latter recognizing complement receptor type 3. Immunology. 1986;57(2):239-247.

194. Miwa T, Furukawa S, Nakajima K, Furukawa Y, Kohsaka S. Lipopolysaccharide enhances synthesis of brain-derived neurotrophic factor in cultured rat microglia. J Neurosci Res. 1997;50(6): 1023-1029.

195. Nicholas RS, Stevens S, Wing MG, Compston DA. Microglia-derived IGF-2 prevents TNFalpha induced death of mature oligodendrocytes in vitro. J Neuroimmunol. 2002;124(1-2):36-44.

196. Garaci E, Caroleo MC, Aloe L, et al. Nerve growth factor is an autocrine factor essential for the survival of macrophages infected with HIV. Proc Natl Acad Sci U S A. 1999;96(24):14013-14018.

197. Chao CC, Hu S, Sheng WS, Peterson PK. Tumor necrosis factoralpha production by human fetal microglial cells: regulation by other cytokines. Dev Neurosci. 1995;17(2):97-105.

198. Kullander K, Kylberg A, Ebendal T. Specificity of neurotrophin-3 determined by loss-of-function mutagenesis. J Neurosci Res. 1997; 50(3):496-503.

199. Batchelor PE, Liberatore GT, Wong JY, et al. Activated macrophages and microglia induce dopaminergic sprouting in the injured striatum and express brain-derived neurotrophic factor and glial cell line-derived neurotrophic factor. J Neurosci. 1999;19(5): $1708-1716$

200. Kerschensteiner M, Gallmeier E, Behrens L, et al. Activated human T cells, B cells, and monocytes produce brain-derived neurotrophic factor in vitro and in inflammatory brain lesions: a neuroprotective role of inflammation? J Exp Med. 1999;189(5):865-870.

201. Ziemssen T, Kumpfel T, Klinkert WE, Neuhaus O, Hohlfeld R. Glatiramer acetate-specific T-helper 1- and 2-type cell lines produce BDNF: implications for multiple sclerosis therapy. Brain-derived neurotrophic factor. Brain. 2002;125(Pt 11):2381-2391.

202. Chen M, Valenzuela RM, Dhib-Jalbut S. Glatiramer acetate-reactive T cells produce brain-derived neurotrophic factor. J Neurol Sci. 2003;215(1-2):37-44.

203. Kuo HS, Tsai MJ, Huang MC, et al. Acid fibroblast growth factor and peripheral nerve grafts regulate Th2 cytokine expression, macrophage activation, polyamine synthesis, and neurotrophin expression in transected rat spinal cords. J Neurosci. 2011;31(11): 4137-4147.

204. Lisak RP, Benjamins JA, Bealmear B, et al. Differential effects of Th1, monocyte/macrophage and Th2 cytokine mixtures on early gene expression for glial and neural-related molecules in central nervous system mixed glial cell cultures: neurotrophins, growth factors and structural proteins. J Neuroinflammation. 2007;4:30.

205. Benner EJ, Mosley RL, Destache CJ, et al. Therapeutic immunization protects dopaminergic neurons in a mouse model of Parkinson's disease. Proc Natl Acad Sci U S A. 2004;101(25):9435-9440.

206. Chertoff M, Di Paolo N, Schoeneberg A, et al. Neuroprotective and neurodegenerative effects of the chronic expression of tumor necrosis factor $\alpha$ in the nigrostriatal dopaminergic circuit of adult mice. Exp Neurol. 2011;227(2):237-251.

207. Dolga AM, Granic I, Blank T, et al. TNF-alpha-mediates neuroprotection against glutamate-induced excitotoxicity via NFkappaB-dependent up-regulation of K2. 2 channels. J Neurochem. 2008;107(4):1158-1167.

208. Turrin NP, Rivest S. Tumor necrosis factor $\alpha$ but not interleukin $1 \beta$ mediates neuroprotection in response to acute nitric oxide excitotoxicity. J Neurosci. 2006;26(1):143-151.

209. Orellana DI, Quintanilla RA, Maccioni RB. Neuroprotective effect of TNFalpha against the beta-amyloid neurotoxicity mediated by CDK 5 kinase. Biochim Biophys Acta. 2007;1773(2):254-263.

210. Fine SM, Angel RA, Perry SW, et al. Tumor necrosis factor alpha inhibits glutamate uptake by primary human astrocytes. Implications for pathogenesis of HIV-1 dementia. J Biol Chem. 1996;271(26):15303-15306. 
211. Zou JY, Crews FT. TNF alpha potentiates glutamate neurotoxicity by inhibiting glutamate uptake in organotypic brain slice cultures: neuroprotection by NF kappa B inhibition. Brain Res. 2005;1034(1-2): 11-24.

212. Nakaizumi A, Horie T, Kida T, et al. Nitric oxide potentiates TNF$\alpha$-induced neurotoxicity through suppression of NF-кB. Cell Mol Neurobiol. 2012;32(1):95-106.

213. Williams R, Yao H, Dhillon NK, Buch SJ. HIV-1 Tat co-operates with IFN-gamma and TNF-alpha to increase CXCL10 in human astrocytes. PLoS One. 2009;4(5):e5709.

214. Matzen K, Dirkx AE, oude Egbrink MG, et al. HIV-1 Tat increases the adhesion of monocytes and T-cells to the endothelium in vitro and in vivo: implications for AIDS-associated vasculopathy. Virus Res. 2004;104(2):145-155.

215. Jiang J, Fu W, Wang X, Lin PH, Yao Q, Chen C. HIV gp120 induces endothelial dysfunction in tumour necrosis factor-alpha-activated porcine and human endothelial cells. Cardiovasc Res. 2010;87(2): 366-374.

216. Brabers NA, Nottet HS. Role of the pro-inflammatory cytokines TNFalpha and IL-1beta in HIV-associated dementia. Eur J Clin Invest 2006;36(7):447-458.

217. Kfutwah AK, Mary JY, Nicola MA, et al. Tumour necrosis factor-alpha stimulates HIV-1 replication in single-cycle infection of human term placental villi fragments in a time, viral dose and envelope dependent manner. Retrovirology. 2006;3:36.

218. Haraguchi S, Day NK, Kamchaisatian W, et al. LMP-420, a smallmolecule inhibitor of TNF-alpha, reduces replication of HIV-1 and Mycobacterium tuberculosis in human cells. AIDS Res Ther. 2006;3:8

219. Boven LA, Vergnolle N, Henry SD, et al. Up-regulation of proteinaseactivated receptor 1 expression in astrocytes during HIV encephalitis. J Immunol. 2003;170(5):2638-2646.

220. Anderson CE, Tomlinson GS, Pauly B, et al. Relationship of Nefpositive and GFAP-reactive astrocytes to drug use in early and late HIV infection. Neuropathol Appl Neurobiol. 2003;29(4):378-388.

221. Chauhan A, Hahn S, Gartner S, et al. Molecular programming of endothelin-1 in HIV-infected brain: role of Tat in up-regulation of ET-1 and its inhibition by statins. FASEB J. 2007;21(3): 777-789

222. Croitoru-Lamoury J, Guillemin GJ, Boussin FD, et al. Expression of chemokines and their receptors in human and simian astrocytes: evidence for a central role of TNF alpha and IFN gamma in CXCR4 and CCR5 modulation. Glia. 2003;41(4):354-370.

223. Ronaldson PT, Bendayan R. HIV-1 viral envelope glycoprotein gp 120 triggers an inflammatory response in cultured rat astrocytes and regulates the functional expression of P-glycoprotein. Mol Pharmacol. 2006;70(3):1087-1098

224. Schweighardt B, Atwood WJ. HIV type 1 infection of human astrocytes is restricted by inefficient viral entry. AIDS Res Hum Retroviruses 2001;17(12):1133-1142.

225. Liu Y, Liu H, Kim BO, et al. CD4-independent infection of astrocytes by human immunodeficiency virus type 1 : requirement for the human mannose receptor. J Virol. 2004;78(8):4120-4133.

226. Chen P, Mayne M, Power C, Nath A. The Tat protein of HIV-1 induces tumor necrosis factor-alpha production: implications for HIV1-associated neurological diseases. J Biol Chem. 1997;272(36): 22385-22388.

227. Mollace V, Salvemini D, Riley DP, et al. The contribution of oxidative stress in apoptosis of human-cultured astroglial cells induced by supernatants of HIV-1-infected macrophages. J Leukoc Biol. 2002;71(1):65-72.

228. Zhang K, McQuibban GA, Silva C, et al. HIV-induced metalloproteinase processing of the chemokine stromal cell derived factor- 1 causes neurodegeneration. Nat Neurosci. 2003;6(10):1064-1071.

229. Rappaport J, Joseph J, Croul S, et al. Molecular pathway involved in HIV-1-induced CNS pathology: role of viral regulatory protein, Tat. J Leukoc Biol. 1999;65(4):458-465.
230. Nath A. Human immunodeficiency virus-associated neurocognitive disorder: pathophysiology in relation to drug addiction. Ann NY Acad Sci. 2010;1187:122-128.

231. Li J, Bentsman G, Potash MJ, Volsky DJ. Human immunodeficiency virus type 1 efficiently binds to human fetal astrocytes and induces neuroinflammatory responses independent of infection. $B M C$ Neurosci. 2007;8:31.

232. Khan NA, Di Cello F, Nath A, Kim KS. Human immunodeficiency virus type 1 tat-mediated cytotoxicity of human brain microvascular endothelial cells. J Neurovirol. 2003;9(6):584-593.

233. Kim TA, Avraham HK, Koh YH, Jiang S, Park IW, Avraham S. HIV-1 Tat-mediated apoptosis in human brain microvascular endothelial cells. J Immunol. 2003;170(5):2629-2637.

234. Ullrich CK, Groopman JE, Ganju RK. HIV-1 gp120- and gp160induced apoptosis in cultured endothelial cells is mediated by caspases. Blood. 2000;96(4):1438-1442.

235. Park IW, Ullrich CK, Schoenberger E, Ganju RK, Groopman JE. HIV-1 Tat induces microvascular endothelial apoptosis through caspase activation. J Immunol. 2001;167(5):2766-2771.

236. Price TO, Uras F, Banks WA, Ercal N. A novel antioxidant $\mathrm{N}$-acetylcysteine amide prevents gp120- and Tat-induced oxidative stress in brain endothelial cells. Exp Neurol. 2006;201(1):193-202.

237. Acheampong EA, Parveen Z, Muthoga LW, Kalayeh M, Mukhtar M, Pomerantz RJ. Human immunodeficiency virus type 1 Nef potently induces apoptosis in primary human brain microvascular endothelial cells via the activation of caspases. J Virol. 2005;79(7):4257-4269.

238. Ren Z, Yao Q, Chen C. HIV-1 envelope glycoprotein 120 increases intercellular adhesion molecule-1 expression by human endothelial cells. Lab Invest. 2002;82(3):245-255.

239. Pieper GM, Olds CL, Bub JD, Lindholm PF. Transfection of human endothelial cells with HIV-1 tat gene activates NF-kappa B and enhances monocyte adhesion. Am J Physiol Heart Circ Physiol. 2002; 283(6):H2315-H2321.

240. Andras IE, Pu H, Deli MA, Nath A, Hennig B, Toborek M. HIV-1 Tat protein alters tight junction protein expression and distribution in cultured brain endothelial cells. J Neurosci Res. 2003;74(2): 255-265.

241. Price TO, Ercal N, Nakaoke R, Banks WA. HIV-1 viral proteins gp120 and Tat induce oxidative stress in brain endothelial cells. Brain Res 2005;1045(1-2):57-63.

242. Lu TS, Avraham HK, Seng S, et al. Cannabinoids inhibit HIV-1 Gp120-mediated insults in brain microvascular endothelial cells. J Immunol. 2008;181(9):6406-6416.

243. Afonso PV, Ozden S, Cumont MC, et al. Alteration of blood-brain barrier integrity by retroviral infection. PLoS Pathog. 2008;4(11): e1000205.

244. Enting RH, Hoetelmans RM, Lange JM, Burger DM, Beijnen JH, Portegies P. Antiretroviral drugs and the central nervous system. AIDS. 1998;12(15):1941-1955

245. Karkan D, Pfeifer C, Vitalis TZ, et al. A unique carrier for delivery of therapeutic compounds beyond the blood-brain barrier. PLoS One. 2008;3(6):e2469.

246. Bennewitz MF, Saltzman WM. Nanotechnology for delivery of drugs to the brain for epilepsy. Neurotherapeutics. 2009;6(2):323-336.

247. Liu S, Levine SR, Winn HR. Targeting ischemic penumbra. Part II: selective drug delivery using liposome technologies. J Exp Stroke Transl Med. 2011;4(1):16-23.

248. Simpson DM, Elliott KJ, McArthur J. Peripheral neuropathy. In: Gendelman HE, Grant I, Everall IP, et al, editors. The Neurology of AIDS. 3rd ed. New York, NY: Oxford University Press; 2012: 536-546.

249. Wasti SP, Simkhada P, Randall J, van Teijlingen E. Issues and challenges of HIV/AIDS prevention and treatment programme in Nepal. Glob J Health Sci. 2009;1(2):62-72.

250. Selwyn PA, Rivard M. Palliative care for AIDS: challenges and opportunities in the era of highly active anti-retroviral therapy. J Palliat Med. 2003;6(3):475-487. 
251. Shehu-Xhilaga M, Tachedjian G, Crowe SM, Kedzierska K. Antiretroviral compounds: mechanisms underlying failure of HAART to eradicate HIV-1. Curr Med Chem. 2005;12(15):1705-1719.

252. Canestri A, Lescure FX, Jaureguiberry S, et al. Discordance between cerebral spinal fluid and plasma HIV replication in patients with neurological symptoms who are receiving suppressive antiretroviral therapy. Clin Infect Dis. 2010;50(5):773-778.

253. AIDSinfo; United States Department of Health and Human Services. Guidelines for the use of antiretroviral agents in HIV-1-infected adults and adolescents. October 14, 2011. Available from: http://www. aidsinfo.nih.gov/contentfiles/lvguidelines/adultandadolescentgl.pdf. Accessed August 16, 2012

254. Ene L, Duiculescu D, Ruta SM. How much do antiretroviral drugs penetrate into the central nervous system? J Med Life. 2011;4(4): 432-439.

255. Brew BJ. Benefit or toxicity from neurologically targeted antiretroviral therapy? Clin Infect Dis. 2010;50(6):930-932.

256. Han RZ, Hu JJ, Weng YC, Li DF, Huang Y. NMDA receptor antagonist MK-801 reduces neuronal damage and preserves learning and memory in a rat model of traumatic brain injury. Neurosci Bull. 2009;25(6):367-375.

257. Toggas SM, Masliah E, Mucke L. Prevention of HIV-1 gp120-induced neuronal damage in the central nervous system of transgenic mice by the NMDA receptor antagonist memantine. Brain Res. 1996;706(2): 303-307.

258. Lipton SA. Erythropoietin for neurologic protection and diabetic neuropathy. N Engl J Med. 2004;350(24):2516-2517.

259. Alisky JM. Could cholinesterase inhibitors and memantine alleviate HIV dementia? J Acquir Immune Defic Syndr. 2005;38(1): 113-114.

260. Anderson ER, Gendelman HE, Xiong H. Memantine protects hippocampal neuronal function in murine human immunodeficiency virus type 1 encephalitis. $J$ Neurosci. 2004;24(32):7194-7198.

261. Xia P, Chen HS, Zhang D, Lipton SA. Memantine preferentially blocks extrasynaptic over synaptic NMDA receptor currents in hippocampal autapses. J Neurosci. 2010;30(33):11246-11250.

262. Schifitto G, Navia BA, Yiannoutsos CT, et al. Memantine and HIV-associated cognitive impairment: a neuropsychological and proton magnetic resonance spectroscopy study. AIDS. 2007;21(14): $1877-1886$.

263. Doody R, Wirth Y, Schmitt F, Mobius HJ. Specific functional effects of memantine treatment in patients with moderate to severe Alzheimer's disease. Dement Geriatr Cogn Disord. 2004;18(2):227-232.

264. Reisberg B, Doody R, Stoffler A, et al. Memantine in moderate-to-severe Alzheimer's disease. N Engl J Med. 2003;348(14):1333-1341.

265. Winblad B, Poritis N. Memantine in severe dementia: results of the 9M-Best Study (benefit and efficacy in severely demented patients during treatment with memantine). Int J Geriatr Psychiatry. 1999; 14(2):135-146.

266. Farlow MR, Graham SM, Alva G. Memantine for the treatment of Alzheimer's disease: tolerability and safety data from clinical trials. Drug Saf. 2008;31(7):577-585.

267. Kavirajan H. Memantine: a comprehensive review of safety and efficacy. Expert Opin Drug Saf. 2009;8(1):89-109.

268. de Carvalho M, Pinto S, Costa J, Evangelista T, Ohana B, Pinto A. A randomized, placebo-controlled trial of memantine for functional disability in amyotrophic lateral sclerosis. Amyotroph Lateral Scler. 2010;11(5):456-460

269. Zhao Y, Navia BA, Marra CM, et al. Memantine for AIDS dementia complex: open-label report of ACTG 301. HIV Clin Trials. 2010;11(1): $59-67$.

270. Turchan J, Sacktor N, Wojna V, Conant K, Nath A. Neuroprotective therapy for HIV dementia. Curr HIV Res. 2003;1(4):373-383.

271. Schifitto G, Sacktor N, Marder K, et al; Neurological AIDS Research Consortium. Randomized trial of the platelet-activating factor antagonist lexipafant in HIV-associated cognitive impairment. Neurology. 1999;53(2):391-396.
272. Navia BA, Dafni U, Simpson D, et al. A phase I/II trial of nimodipine for HIV-related neurologic complications. Neurology. 1998;51(1): 221-228.

273. Deng Y, Fang W, Li Y, et al. Blood-brain barrier breakdown by PAF and protection by XQ-1H due to antagonism of PAF effects. Eur $J$ Pharmacol. 2009;616(1-3):43-47.

274. van Patot MC, Keyes LE, Leadbetter G 3rd, Hackett PH. Ginkgo biloba for prevention of acute mountain sickness: does it work? High Alt Med Biol. 2009;10(1):33-43.

275. Dube B, Benton T, Cruess DG, Evans DL. Neuropsychiatric manifestations of HIV infection and AIDS. $J$ Psychiatry Neurosci. 2005;30(4):237-246.

276. Heseltine PN, Goodkin K, Atkinson JH, et al. Randomized doubleblind placebo-controlled trial of peptide $\mathrm{T}$ for HIV-associated cognitive impairment. Arch Neurol. 1998;55(1):41-51.

277. Clifford DB, McArthur JC, Schifitto G, et al. A randomized clinical trial of CPI-1189 for HIV-associated cognitive-motor impairment. Neurology. 2002;59(10):1568-1573.

278. The Dana Consortium on the Therapy of HIV Dementia and Related Cognitive Disorders. Safety and tolerability of the antioxidant OPC14117 in HIV-associated cognitive impairment. Neurology. 1997; 49(1):142-146.

279. The Dana Consortium on the Therapy of HIV Dementia and Related Cognitive Disorders. A randomized, double-blind, placebo-controlled trial of deprenyl and thioctic acid in human immunodeficiency virusassociated cognitive impairment. Neurology. 1998;50(3):645-651.

280. Sacktor N, Schifitto G, McDermott MP, Marder K, McArthur JC, Kieburtz K. Transdermal selegiline in HIV-associated cognitive impairment: pilot, placebo-controlled study. Neurology. 2000;54(1): 233-235.

281. Schifitto G, Zhang J, Evans SR, et al. A multicenter trial of selegiline transdermal system for HIV-associated cognitive impairment. Neurology. 2007;69(13):1314-1321.

282. Schifitto G, Yiannoutsos CT, Ernst T, et al. Selegiline and oxidative stress in HIV-associated cognitive impairment. Neurology. 2009; 73(23):1975-1981.

283. Letendre SL, Woods SP, Ellis RJ, et al. Lithium improves HIV-associated neurocognitive impairment. AIDS. 2006;20(14):1885-1888.

284. Schifitto G, Zhong J, Gill D, et al. Lithium therapy for human immunodeficiency virus type 1-associated neurocognitive impairment. J Neurovirol. 2009;15(2):176-186.

285. Sacktor N, Miyahara S, Deng L, et al. Minocycline treatment for HIV-associated cognitive impairment: results from a randomized trial. Neurology. 2011;77(12):1135-1142.

286. Schifitto G, Peterson DR, Zhong J, et al. Valproic acid adjunctive therapy for HIV-associated cognitive impairment: a first report. Neurology. 2006;66(6):919-921.

287. Dou H, Kingsley JD, Mosley RL, Gelbard HA, Gendelman HE. Neuroprotective strategies for HIV-1 associated dementia. Neurotox Res. 2004;6(7-8):503-521.

288. Chen G, Huang LD, Jiang YM, Manji HK. The mood-stabilizing agent valproate inhibits the activity of glycogen synthase kinase-3. J Neurochem. 1999;72(3):1327-1330.

289. Li D, August S, Woulfe DS. GSK3beta is a negative regulator of platelet function and thrombosis. Blood. 2008;111(7):3522-3530.

290. Barry FA, Graham GJ, Fry MJ, Gibbins JM. Regulation of glycogen synthase kinase 3 in human platelets: a possible role in platelet function? FEBS Lett. 2003;553(1-2):173-178.

291. Maggirwar SB, Tong N, Ramirez S, Gelbard HA, Dewhurst S. HIV-1 Tat-mediated activation of glycogen synthase kinase-3beta contributes to Tat-mediated neurotoxicity. J Neurochem. 1999;73(2):578-586.

292. Gelbard HA, Nottet HS, Swindells S, et al. Platelet-activating factor: a candidate human immunodeficiency virus type 1-induced neurotoxin. J Virol. 1994;68(7):4628-4635.

293. Hall AC, Brennan A, Goold RG, et al. Valproate regulates GSK-3mediated axonal remodeling and synapsin I clustering in developing neurons. Mol Cell Neurosci. 2002;20(2):257-270. 
294. Koivisto L, Alavian K, Hakkinen L, Pelech S, McCulloch CA, Larjava H. Glycogen synthase kinase-3 regulates formation of long lamellipodia in human keratinocytes. $J$ Cell Sci. 2003;116(Pt 18): 3749-3760.

295. Chen S, Hillman DE. Immunohistochemical localization of protein kinase $\mathrm{C}$ delta during postnatal development of the cerebellum. Brain Res Dev Brain Res. 1994;80(1-2):19-25.

296. Manji HK, McNamara R, Chen G, Lenox RH. Signalling pathways in the brain: cellular transduction of mood stabilisation in the treatment of manic-depressive illness. Aust N Z J Psychiatry. 1999;33(Suppl): S65-S83.

297. Lenox RH, McNamara RK, Watterson JM, Watson DG. Myristoylated alanine-rich C kinase substrate (MARCKS): a molecular target for the therapeutic action of mood stabilizers in the brain? J Clin Psychiatry. 1996;57(Suppl 13):S23-S31.

298. Cysique LA, Maruff P, Brew BJ. Valproic acid is associated with cognitive decline in HIV-infected individuals: a clinical observational study. BMC Neurol. 2006;6:42.

299. Spera PA, Ellison JA, Feuerstein GZ, Barone FC. IL-10 reduces rat brain injury following focal stroke. Neurosci Lett. 1998;251(3): 189-192.

300. Abraham KE, McMillen D, Brewer KL. The effects of endogenous interleukin-10 on gray matter damage and the development of pain behaviors following excitotoxic spinal cord injury in the mouse. Neuroscience. 2004;124(4):945-952.

301. Dietrich WD, Busto R, Bethea JR. Postischemic hypothermia and IL-10 treatment provide long-lasting neuroprotection of CA1 hippocampus following transient global ischemia in rats. Exp Neurol. 1999;158(2):444-450.

302. Sholl-Franco A, Marques PM, Ferreira CM, de Araujo EG IL-4 increases GABAergic phenotype in rat retinal cell cultures: involvement of muscarinic receptors and protein kinase $\mathrm{C}$. J Neuroimmunol. 2002;133(1-2):20-29.

303. Huang P, Zhang SS, Zhang C. Erratum: the two sides of cytokine signaling and glaucomatous optic neuropathy. J Ocul Biol Dis Infor. 2009;2(3):98-103.

304. Digicaylioglu M, Garden G, Timberlake S, Fletcher L, Lipton SA. Acute neuroprotective synergy of erythropoietin and insulin-like growth factor I. Proc Natl Acad Sci U S A. 2004;101(26):9855-9860.

305. Kim I, Kim CH, Yim YS, Ahn YS. Autocrine function of erythropoietin in IGF-1-induced erythropoietin biosynthesis. Neuroreport. 2008; 19(17):1699-1703.

306. Wu C, Cao S, Maggirwar S, Dewhurst S, Lu Y. Construction and characterization of lentiviral vector-mediated expression of TNFR as a potential protective molecule in human neuronal cells [abstract]. J Neuroimmune Pharmacol. 2012;7(Suppl 1):S60.

307. Bruno V, Copani A, Besong G, Scoto G, Nicoletti F. Neuroprotective activity of chemokines against N-methyl-D-aspartate or beta-amyloidinduced toxicity in culture. Eur J Pharmacol. 2000;399(2-3): $117-121$.

308. Cook A, Hippensteel R, Shimizu S, Nicolai J, Fatatis A, Meucci O. Interactions between chemokines: regulation of fractalkine/CX3CL1 homeostasis by SDF/CXCL12 in cortical neurons. J Biol Chem. 2010;285(14):10563-10571.

309. Kaul M, Lipton SA. Signaling pathways to neuronal damage and apoptosis in human immunodeficiency virus type 1-associated dementia: chemokine receptors, excitotoxicity, and beyond. J Neurovirol. 2004;10(Suppl 1):97-101.

310. Connor B, Dragunow M. The role of neuronal growth factors in neurodegenerative disorders of the human brain. Brain Res Brain Res Rev. 1998;27(1):1-39.

311. Moalem G, Gdalyahu A, Shani Y, et al. Production of neurotrophins by activated $\mathrm{T}$ cells: implications for neuroprotective autoimmunity. J Autoimmun. 2000;15(3):331-345.

312. Dou H, Birusingh K, Faraci J, et al. Neuroprotective activities of sodium valproate in a murine model of human immunodeficiency virus-1 encephalitis. J Neurosci. 2003;23(27):9162-9170.
313. Paula-Barbosa MM, Pereira PA, Cadete-Leite A, Dulce Madeira M. NGF and NT-3 exert differential effects on the expression of neuropeptides in the suprachiasmatic nucleus of rats withdrawn from ethanol treatment. Brain Res. 2003;983(1-2):64-73.

314. Meeker RB, Poulton W, Feng WH, Hudson L, Longo FM. Suppression of immunodeficiency virus-associated neural damage by the p75 neurotrophin receptor ligand, LM11A-31, in an in vitro feline model. J Neuroimmune Pharmacol. 2012;7(2):388-400.

315. Chauhan NB, Siegel GJ, Lee JM. Depletion of glial cell line-derived neurotrophic factor in substantia nigra neurons of Parkinson's disease brain. J Chem Neuroanat. 2001;21(4):277-288.

316. Felderhoff-Mueser U, Sifringer M, Pesditschek S, et al. Pathways leading to apoptotic neurodegeneration following trauma to the developing rat brain. Neurobiol Dis. 2002;11(2):231-245.

317. Johnson VJ, Sharma RP. Aluminum disrupts the pro-inflammatory cytokine/neurotrophin balance in primary brain rotation-mediated aggregate cultures: possible role in neurodegeneration. Neurotoxicology. 2003;24(2):261-268

318. Meucci O, Miller RJ. Gp120-induced neurotoxicity in hippocampal pyramidal neuron cultures: protective action of TGF-beta1. JNeurosci. 1996;16(13):4080-4088.

319. Ramirez SH, Sanchez JF, Dimitri CA, Gelbard HA, Dewhurst S, Maggirwar SB. Neurotrophins prevent HIV Tat-induced neuronal apoptosis via a nuclear factor-kappaB (NF-kappaB)-dependent mechanism. J Neurochem. 2001;78(4):874-889.

320. Titanji K, Nilsson A, Morch C, et al. Low frequency of plasma nervegrowth factor detection is associated with death of memory B lymphocytes in HIV-1 infection. Clin Exp Immunol. 2003;132(2):297-303.

321. Bachis A, Major EO, Mocchetti I. Brain-derived neurotrophic factor inhibits human immunodeficiency virus-1/gp120-mediated cerebellar granule cell death by preventing gp120 internalization. $J$ Neurosci. 2003;23(13):5715-5722.

322. Mocchetti I, Nosheny RL, Tanda G, Ren K, Meyer EM. Brain-derived neurotrophic factor prevents human immunodeficiency virus type 1 protein gp120 neurotoxicity in the rat nigrostriatal system. Ann NY Acad Sci. 2007;1122:144-154.

323. Everall IP, Trillo-Pazos G, Bell C, Mallory M, Sanders V, Masliah E. Amelioration of neurotoxic effects of HIV envelope protein gp 120 by fibroblast growth factor: a strategy for neuroprotection. J Neuropathol Exp Neurol. 2001;60(3):293-301.

324. Zou CG, Cao XZ, Zhao YS, et al. The molecular mechanism of endoplasmic reticulum stress-induced apoptosis in PC-12 neuronal cells: the protective effect of insulin-like growth factor I. Endocrinology. 2009;150(1):277-285.

325. Poser S, Impey S, Xia Z, Storm DR. Brain-derived neurotrophic factor protection of cortical neurons from serum withdrawal-induced apoptosis is inhibited by cAMP. $J$ Neurosci. 2003;23(11):4420-4427.

326. Hellman M, Arumae U, Yu LY, et al. Mesencephalic astrocyte-derived neurotrophic factor (MANF) has a unique mechanism to rescue apoptotic neurons. J Biol Chem. 2011;286(4):2675-2680.

327. Zhang J, Shi Q, Chen X, et al. Retroviral vector-mediated hypoxiaregulated neurotrophin-3 gene transfer reduces apoptosis induced by hypoxia in PC12 cells. Mol Neurodegener. 2012;7(Suppl 1):S17.

328. Nguyen N, Lee SB, Lee YS, Lee KH, Ahn JY. Neuroprotection by NGF and BDNF against neurotoxin-exerted apoptotic death in neural stem cells are mediated through Trk receptors, activating PI3-kinase and MAPK pathways. Neurochem Res. 2009;34(5):942-951.

329. Yuan J, Yankner BA. Apoptosis in the nervous system. Nature. 2000;407(6805):802-809.

330. Cid C, Alvarez-Cermeno JC, Regidor I, Plaza J, Salinas M, Alcazar A. Caspase inhibitors protect against neuronal apoptosis induced by cerebrospinal fluid from multiple sclerosis patients. J Neuroimmunol. 2003;136(1-2):119-124.

331. Hanko E, Hansen TW, Almaas R, Paulsen R, Rootwelt T. Synergistic protection of a general caspase inhibitor and MK- 801 in bilirubininduced cell death in human NT2-N neurons. Pediatr Res. 2006;59(1): $72-77$. 
332. Yang Y, Zhu X, Chen Y, Wang X, Chen R. p38 and JNK MAPK, but not ERK1/2 MAPK, play important role in colchicine-induced cortical neurons apoptosis. Eur J Pharmacol. 2007;576(1-3):26-33.

333. Medders KE, Sejbuk NE, Maung R, Desai MK, Kaul M. Activation of p38 MAPK is required in monocytic and neuronal cells for HIV glycoprotein 120-induced neurotoxicity. J Immunol. 2010;185(8):4883-4895.

334. Neubert M, Ridder DA, Bargiotas P, Akira S, Schwaninger M. Acute inhibition of TAK1 protects against neuronal death in cerebral ischemia. Cell Death Differ. 2011;18(9):1521-1530.

335. Gao F, Bailes E, Robertson DL, et al. Origin of HIV-1 in the chimpanzee Pan troglodytes troglodytes. Nature. 1999;397(6718):436-441.

336. Van Rompay KK. Evaluation of antiretrovirals in animal models of HIV infection. Antiviral Res. 2010;85(1):159-175.

337. Gardner MB. Historical perspective. In: Friedman H, Specter S, Bendinelli M, editors. In Vivo Models of HIV Disease and Control. New York, NY: Springer; 2006:1-18.

338. Balzarini J, Vahlenkamp T, Egberink H, et al. Antiretroviral activities of acyclic nucleoside phosphonates (9-[2- phosphonylmethoxyethyl] adenine, 9-[2-phosphonylmethoxyethyl]guanine, [R]-9-[2phosphonylmethoxypropyl]adenine, and MDL 74,968) in cell cultures and murine sarcoma virus-infected newborn NMRI mice. Antimicrob Agents Chemother. 1997;41(3):611-616.

339. Ruprecht RM, O’Brien LG, Rossoni LD, Nusinoff-Lehrman S. Suppression of mouse viraemia and retroviral disease by $3^{\prime}$-azido-3'deoxythymidine. Nature. 1986;323(6087):467-469.

340. Maddon PJ, Dalgleish AG, McDougal JS, Clapham PR, Weiss RA, Axel R. The T4 gene encodes the AIDS virus receptor and is expressed in the immune system and the brain. Cell. 1986;47(3):333-348.

341. Levy JA, Cheng-Mayer C, Dina D, Luciw PA. AIDS retrovirus (ARV-2) clone replicates in transfected human and animal fibroblasts. Science. 1986;232(4753):998-1001.

342. Wu C, Lu Y. High-titre retroviral vector system for efficient gene delivery into human and mouse cells of haematopoietic and lymphocytic lineages. J Gen Virol. 2010;91(Pt 8):1909-1918.

343. Zheng YH, Yu HF, Peterlin BM. Human p32 protein relieves a posttranscriptional block to HIV replication in murine cells. Nat Cell Biol. 2003;5(7):611-618.

344. Winslow BJ, Trono D. The blocks to human immunodeficiency virus type 1 Tat and Rev functions in mouse cell lines are independent. J Virol. 1993;67(4):2349-2354.

345. Goffinet C, Allespach I, Keppler OT. HIV-susceptible transgenic rats allow rapid preclinical testing of antiviral compounds targeting virus entry or reverse transcription. Proc Natl Acad Sci USA. 2007;104(3): 1015-1020.

346. Michel N, Goffinet C, Ganter K, et al. Human cyclin T1 expression ameliorates a T-cell-specific transcriptional limitation for HIV in transgenic rats, but is not sufficient for a spreading infection of prototypic R5 HIV-1 strains ex vivo. Retrovirology. 2009;6:2.

347. Toggas SM, Masliah E, Rockenstein EM, Rall GF, Abraham CR, Mucke L. Central nervous system damage produced by expression of the HIV-1 coat protein gp120 in transgenic mice. Nature. 1994; 367(6459):188-193.

348. Maung R, Medders KE, Sejbuk NE, Desai MK, Russo R, Kaul M. Genetic knockouts suggest a critical role for HIV co-receptors in models of HIV gp120-induced brain injury. J Neuroimmune Pharmacol. 2012;7(2):306-318.

349. Erichsen D, Lopez AL, Peng H, et al. Neuronal injury regulates fractalkine: relevance for HIV-1 associated dementia. J Neuroimmunol. 2003;138(1-2):144-155.

350. Zhang K, Rana F, Silva C, et al. Human immunodeficiency virus type 1 envelope-mediated neuronal death: uncoupling of viral replication and neurotoxicity. J Virol. 2003;77(12):6899-6912.

351. Kim BO, Liu Y, Ruan Y, Xu ZC, Schantz L, He JJ. Neuropathologies in transgenic mice expressing human immunodeficiency virus type 1 Tat protein under the regulation of the astrocyte-specific glial fibrillary acidic protein promoter and doxycycline. Am J Pathol. 2003;162(5): 1693-1707.
352. Power C, Hui E, Vivithanaporn P, Acharjee S, Polyak M. Delineating HIV-associated neurocognitive disorders using transgenic models: the neuropathogenic actions of Vpr. J Neuroimmune Pharmacol. 2012; 7(2):319-331.

353. Reid W, Sadowska M, Denaro F, et al. An HIV-1 transgenic rat that develops HIV-related pathology and immunologic dysfunction. Proc Natl Acad Sci U S A. 2001;98(16):9271-9276.

354. Chang SL, Connaghan KP. Behavioral and molecular evidence for a feedback interaction between morphine and HIV-1 viral proteins. J Neuroimmune Pharmacol. 2012;7(2):332-340.

355. Altice FL, Kamarulzaman A, Soriano VV, Schechter M, Friedland GH. Treatment of medical, psychiatric, and substance-use comorbidities in people infected with HIV who use drugs. Lancet. 2010;376(9738): 367-387.

356. Hayman M, Arbuthnott G, Harkiss G, et al. Neurotoxicity of peptide analogues of the transactivating protein tat from maedi-visna virus and human immunodeficiency virus. Neuroscience. 1993;53(1): $1-6$.

357. Yao H, Buch S. Rodent models of HAND and drug abuse: exogenous administration of viral protein(s) and cocaine. J Neuroimmune Pharmacol. 2012;7(2):341-351.

358. Kelschenbach JL, Saini M, Hadas E, et al. Mice chronically infected with chimeric HIV resist peripheral and brain superinfection: a model of protective immunity to HIV. J Neuroimmune Pharmacol. 2012;7(2):380-387.

359. Potash MJ, Chao W, Bentsman G, et al. A mouse model for study of systemic HIV-1 infection, antiviral immune responses, and neuroinvasiveness. Proc Natl Acad Sci U S A. 2005;102(10): 3760-3765.

360. Borkow G. Mouse models for HIV-1 infection. IUBMB Life. 2005; 57(12):819-823.

361. Stoddart CA, Reyes RA. Models of HIV-1 disease: a review of current status. Drug Discov Today Dis Models. 2006;3(1):113-119.

362. Denton PW, Estes JD, Sun Z, et al. Antiretroviral pre-exposure prophylaxis prevents vaginal transmission of HIV-1 in humanized BLT mice. PLoS Med. 2008;5(1):e16.

363. Lubin I, Segall H, Marcus H, et al. Engraftment of human peripheral blood lymphocytes in normal strains of mice. Blood. 1994;83(8): 2368-2381.

364. ReisnerY, Dagan S. The Trimera mouse: generating human monoclonal antibodies and an animal model for human diseases. Trends Biotechnol. 1998;16(6):242-246.

365. Denton PW, Garcia JV. Humanized mouse models of HIV infection. AIDS Rev. 2011;13(3):135-148.

366. Gorantla S, Makarov E, Finke-Dwyer J, et al. Links between progressive HIV-1 infection of humanized mice and viral neuropathogenesis. Am J Pathol. 2010;177(6):2938-2949.

367. Dash PK, Gorantla S, Gendelman HE, et al. Loss of neuronal integrity during progressive HIV-1 infection of humanized mice. J Neurosci. 2011;31(9):3148-3157.

368. Gorantla S, Poluektova L, Gendelman HE. Rodent models for HIVassociated neurocognitive disorders. Trends Neurosci. 2012;35(3): 197-208.

369. Gong N, Liu J, Reynolds AD, Gorantla S, Mosley RL, Gendelman HE. Brain ingress of regulatory $\mathrm{T}$ cells in a murine model of HIV-1 encephalitis. J Neuroimmunol. 2011;230(1-2):33-41.

370. Sparger EE. FIV as a model for HIV: an overview. In: Friedman H, Specter S, Bendinelli M, editors. In Vivo Models of HIV Disease and Control. New York, NY: Springer; 2006:149-238.

371. Cronn RC, Remington KM, Preston BD, North TW. Inhibition of reverse transcriptase from feline immunodeficiency virus by ana$\operatorname{logs}$ of 2'-deoxyadenosine-5'-triphosphate. Biochem Pharmacol. 1992;44(7):1375-1381.

372. Hartmann K, Donath A, Beer B, et al. Use of two virustatica (AZT, PMEA) in the treatment of FIV and of FeLV seropositive cats with clinical symptoms. Vet Immunol Immunopathol. 1992;35(1-2): 167-175. 
373. Hartmann K, Kuffer M, Balzarini J, et al. Efficacy of the acyclic nucleoside phosphonates (S)-9-(3-fluoro-2-phosphonylmethoxypropyl) adenine (FPMPA) and 9-(2-phosphonylmethoxyethyl)adenine (PMEA) against feline immunodeficiency virus. J Acquir Immune Defic Syndr Hum Retrovirol. 1998;17(2):120-128.

374. North TW, North GL, Pedersen NC. Feline immunodeficiency virus, a model for reverse transcriptase-targeted chemotherapy for acquired immune deficiency syndrome. Antimicrob Agents Chemother. 1989;33(6):915-919.

375. North TW, Cronn RC, Remington KM, Tandberg RT. Direct comparisons of inhibitor sensitivities of reverse transcriptases from feline and human immunodeficiency viruses. Antimicrob Agents Chemother. 1990;34(8):1505-1507.

376. Vahlenkamp TW, De Ronde A, Balzarini J, et al. (R)-9-(2phosphonylmethoxypropyl)-2,6-diaminopurine is a potent inhibitor of feline immunodeficiency virus infection. Antimicrob Agents Chemother. 1995;39(3):746-749.

377. Auwerx J, Esnouf R, De Clercq E, Balzarini J. Susceptibility of feline immunodeficiency virus/human immunodeficiency virus type 1 reverse transcriptase chimeras to non-nucleoside RT inhibitors. Mol Pharmacol. 2004;65(1):244-251.

378. Dean GA, Reubel GH, Moore PF, Pedersen NC. Proviral burden and infection kinetics of feline immunodeficiency virus in lymphocyte subsets of blood and lymph node. J Virol. 1996;70(8):5165-5169.

379. Nath BM, Schumann KE, Boyer JD. The chimpanzee and other nonhuman primate models in HIV-1 vaccine research. Trends Microbiol. 2000;8(9):426-431.

380. Novembre FJ, de Rosayro J, Nidtha S, et al. Rapid CD4(+) T-cell loss induced by human immunodeficiency virus type 1(NC) in uninfected and previously infected chimpanzees. J Virol. 2001;75(3): 1533-1539.

381. Novembre FJ, Saucier M, Anderson DC, et al. Development of AIDS in a chimpanzee infected with human immunodeficiency virus type 1 . J Virol. 1997;71(5):4086-4091.

382. Frumkin LR, Agy MB, Coombs RW, et al. Acute infection of Macaca nemestrina by human immunodeficiency virus type 1. Virology. 1993; 195(2):422-431.

383. Thippeshappa R, Polacino P, Yu Kimata MT, et al. Vif substitution enables persistent infection of pig-tailed macaques by human immunodeficiency virus type 1. J Virol. 2011;85(8):3767-3779.

384. Hatziioannou T, Ambrose Z, Chung NP, et al. A macaque model of HIV-1 infection. Proc Natl Acad Sci US A. 2009;106(11): 4425-4429.

385. Livartowski J, Dormont D, Boussin F, et al. Clinical and virological aspects of HIV2 infection in rhesus monkeys. Cancer Detect Prev. 1992;16(5-6):341-345.

386. Locher CP, Witt SA, Herndier BG, Tenner-Racz K, Racz P, Levy JA. Baboons as an animal model for human immunodeficiency virus pathogenesis and vaccine development. Immunol Rev. 2001;183: $127-140$.

387. Putkonen P, Bottiger B,Warstedt K, Thorstensson R, Albert J, Biberfeld G. Experimental infection of cynomolgus monkeys (Macaca fascicularis) with HIV-2. J Acquir Immune Defic Syndr. 1989;2(4):366-373.

388. Pandrea I, Silvestri G, Apetrei C. AIDS in African nonhuman primate hosts of SIVs: a new paradigm of SIV infection. Curr HIV Res. 2009;7(1):57-72.

389. Silvestri G, Sodora DL, Koup RA, et al. Nonpathogenic SIV infection of sooty mangabeys is characterized by limited bystander immunopathology despite chronic high-level viremia. Immunity. 2003; 18(3):441-452.

390. Silvestri G, Fedanov A, Germon S, et al. Divergent host responses during primary simian immunodeficiency virus SIVsm infection of natural sooty mangabey and nonnatural rhesus macaque hosts. JVirol. 2005;79(7):4043-4054.

391. Gardner MB. Simian AIDS: an historical perspective. J Med Primatol. 2003;32(4-5):180-186.
392. Chahroudi A, Bosinger SE, Vanderford TH, Paiardini M, Silvestri G. Natural SIV hosts: showing AIDS the door. Science. 2012;335(6073): 1188-1193.

393. Daniel MD, Letvin NL, King NW, et al. Isolation of T-cell tropic HTLV-III-like retrovirus from macaques. Science. 1985;228(4704): 1201-1204.

394. Veazey RS, DeMaria M, Chalifoux LV, et al. Gastrointestinal tract as a major site of CD4+ T cell depletion and viral replication in SIV infection. Science. 1998;280(5362):427-431.

395. Haigwood NL, Montefiori DC, Sutton WF, et al. Passive immunotherapy in simian immunodeficiency virus-infected macaques accelerates the development of neutralizing antibodies. JVirol. 2004; 78(11):5983-5995.

396. Lifson JD, Nowak MA, Goldstein S, et al. The extent of early viral replication is a critical determinant of the natural history of simian immunodeficiency virus infection. J Virol. 1997;71(12):9508-9514.

397. Watson A, Ranchalis J, Travis B, et al. Plasma viremia in macaques infected with simian immunodeficiency virus: plasma viral load early in infection predicts survival. J Virol. 1997;71(1):284-290.

398. Ambrose Z, Kewalramani VN, Bieniasz PD, Hatziioannou T. HIV/ AIDS: in search of an animal model. Trends Biotechnol. 2007;25(8): 333-337.

399. Shibata R, Kawamura M, Sakai H, Hayami M, Ishimoto A, Adachi A. Generation of a chimeric human and simian immunodeficiency virus infectious to monkey peripheral blood mononuclear cells. $J$ Virol. 1991;65(7):3514-3520.

400. Li J, Lord CI, Haseltine W, Letvin NL, Sodroski J. Infection of cynomolgus monkeys with a chimeric HIV-1/SIVmac virus that expresses the HIV-1 envelope glycoproteins. J Acquir Immune Defic Syndr. 1992;5(7):639-646.

401. Reimann KA, Li JT, Veazey R, et al. A chimeric simian/human immunodeficiency virus expressing a primary patient human immunodeficiency virus type 1 isolate env causes an AIDS-like disease after in vivo passage in rhesus monkeys. JVirol. 1996;70(10): 6922-6928.

402. Luciw PA, Pratt-Lowe E, Shaw KE, Levy JA, Cheng-Mayer C. Persistent infection of rhesus macaques with T-cell-line-tropic and macrophage-tropic clones of simian/human immunodeficiency viruses (SHIV). Proc Natl Acad Sci U S A. 1995;92(16):7490-7494.

403. Lu Y, Salvato MS, Pauza CD, et al. Utility of SHIV for testing HIV-1 vaccine candidates in macaques. J Acquir Immune Defic Syndr Hum Retrovirol. 1996;12(2):99-106.

404. Harouse JM, Gettie A, Eshetu T, et al. Mucosal transmission and induction of simian AIDS by CCR5-specific simian/human immunodeficiency virus SHIV(SF162P3). J Virol. 2001;75(4): 1990-1995.

405. Song RJ, Chenine AL, Rasmussen RA, et al. Molecularly cloned SHIV1157ipd3N4: a highly replication-competent, mucosally transmissible R5 simian-human immunodeficiency virus encoding HIV clade C Env. J Virol. 2006;80(17):8729-8738.

406. Kraft Z, Derby NR, McCaffrey RA, et al. Macaques infected with a CCR5-tropic simian/human immunodeficiency virus (SHIV) develop broadly reactive anti-HIV neutralizing antibodies. $J$ Virol. 2007;81(12):6402-6411.

407. Ruprecht RM, Baba TW, Liska V, et al. Oral SIV, SHIV, and HIV type 1 infection. AIDS Res Hum Retroviruses. 1998;14(Suppl 1): S97-S103.

408. Lederman MM, Veazey RS, Offord R, et al. Prevention of vaginal SHIV transmission in rhesus macaques through inhibition of CCR5 Science. 2004;306(5695):485-487.

409. Lagenaur LA, Sanders-Beer BE, Brichacek B, et al. Prevention of vaginal SHIV transmission in macaques by a live recombinant Lactobacillus. Mucosal Immunol. 2011;4(6):648-657.

410. Uberla K, Stahl-Hennig C, Bottiger D, et al. Animal model for the therapy of acquired immunodeficiency syndrome with reverse transcriptase inhibitors. Proc Natl Acad Sci U S A. 1995;92(18): 8210-8214. 
411. Witvrouw M, Pannecouque C, Switzer WM, Folks TM, De Clercq E, Heneine W. Susceptibility of HIV-2, SIV and SHIV to various antiHIV-1 compounds: implications for treatment and postexposure prophylaxis. Antivir Ther. 2004;9(1):57-65.

412. Ambrose Z, Boltz V, Palmer S, Coffin JM, Hughes SH, Kewalramani VN. In vitro characterization of a simian immunodeficiency virus-human immunodeficiency virus (HIV) chimera expressing HIV type 1 reverse transcriptase to study antiviral resistance in pigtail macaques. $J$ Virol. 2004;78(24):13553-13561.

413. Ishimatsu M, Suzuki H, Akiyama H, Miura T, Hayami M, Ido E. Construction of a novel SHIV having an HIV-1-derived protease gene and its infection to rhesus macaques: a useful tool for in vivo efficacy tests of protease inhibitors. Microbes Infect. 2007;9(4):475-482.

414. Schmitz JE, Kuroda MJ, Santra S, et al. Control of viremia in simian immunodeficiency virus infection by CD8+ lymphocytes. Science. 1999;283(5403):857-860.
415. Williams K, Burdo TH. Monocyte mobilization, activation markers, and unique macrophage populations in the brain: observations from SIV infected monkeys are informative with regard to pathogenic mechanisms of HIV infection in humans. J Neuroimmune Pharmacol. 2012;7(2):363-371.

416. Weed M, Adams RJ, Hienz RD, et al. SIV/macaque model of HIV infection in cocaine users: minimal effects of cocaine on behavior, virus replication, and CNS inflammation. J Neuroimmune Pharmacol. 2012;7(2):401-411.

417. Winkler JM, Chaudhuri AD, Fox HS. Translating the brain transcriptome in neuroAIDS: from non-human primates to humans. J Neuroimmune Pharmacol. 2012;7(2):372-379.

418. Yelamanchili SV, Chaudhuri AD, Chen LN, Xiong H, Fox HS. MicroRNA-21 dysregulates the expression of MEF2C in neurons in monkey and human SIV/HIV neurological disease. Cell Death Dis. 2010;1:e77.

\section{Publish your work in this journal}

Neurobehavioral HIV Medicine is an international, peer-reviewed, open access journal focusing on advances in research in HIV/ AIDS, with specific reference to the neurological, psychiatric and behavioral consequences of the disease, concomitant infections and specific antiretroviral therapy. The manuscript management system is completely online and includes a very quick and fair peer-review system, which is all easy to use. Visit http://www.dovepress.com/testimonials.php to read real quotes from published authors. 